Sustainability Indices for Military Installations

\title{
An Annotated Bibliography
}

Elisabeth M. Jenicek, Brian M. Deal, and Adam Sagert

US Army Corps of Engineers $\odot$

Engineer Research and Development Center

\section{(2)




\section{Foreword}

This study was conducted for the Directorate of Civil Works, Headquarters, U.S. Army Corps of Engineers (HQUSACE) under Project 622784AT41, "Military Facilities Engineering Technologies"; Work Unit X201, "Sustainable Indices and Metrics." The technical monitor was William D. Goran, CEERD-CVT.

The research was performed by the Energy Branch, of the Facilities Division (CF-E), of the Construction Engineering Research Laboratory (CERL). The CERL principal investigator was Brian M. Deal. Dr. Thomas Hartranft is Chief, CEERDCF-E; and L. Michael Golish is Chief, CEERD-CF. The CERL technical editor was William J. Wolfe, Information Technology Laboratory. The associated Technical Director was Gary W. Schanche, CEERD-CV-T. The Director of CERL is Dr. Alan W. Moore.

CERL is an element of the U.S. Army Engineer Research and Development Center (ERDC), U.S. Army Corps of Engineers. The Commander and Executive Director of ERDC is COL John Morris III, EN and the Director of ERDC is Dr. James R. Houston.

DISCLAIMER: The contents of this report are not to be used for advertising, publication, or promotional purposes. Citation of trade names does not constitute an official endorsement or approval of the use of such commercial products. All product names and trademarks cited are the property of their respective owners. The findings of this report are not to be construed as an official Department of the Army position unless so designated by other authorized documents. 


\section{Contents}

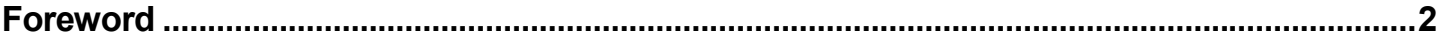

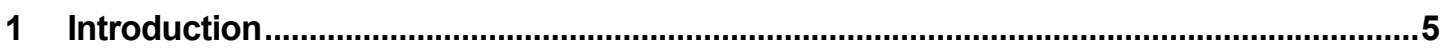

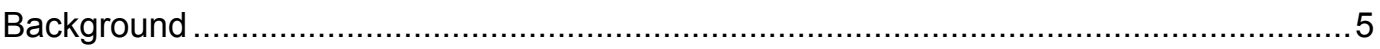

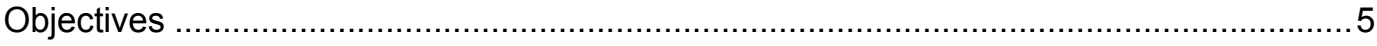

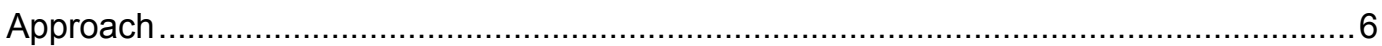

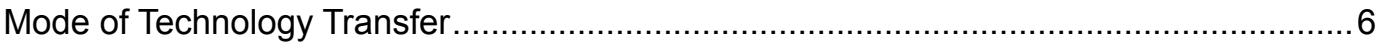

2 Overview of Sustainable Indices Issues ....................................................................

Introduction

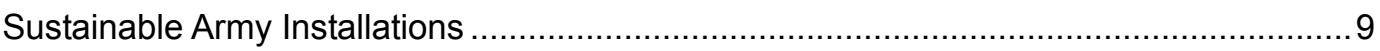

Definitions and Concepts of Sustainability ............................................................. 10

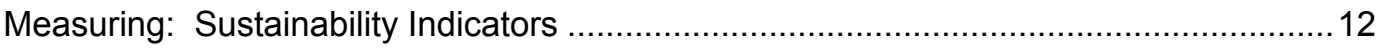

3 Modeling

$4 \quad$ Annotated Bibliography ...........................................................................................18

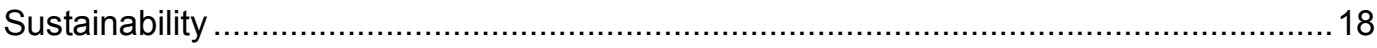

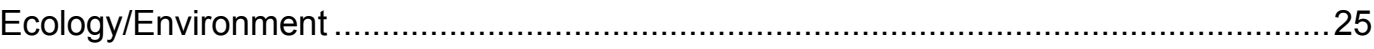

Social/Economics .

Indicators

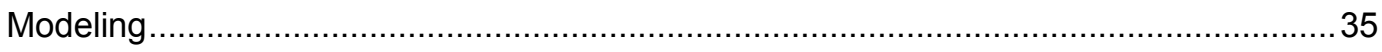

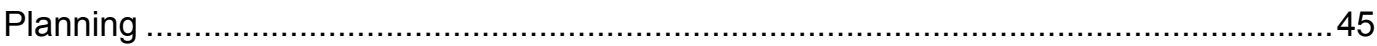

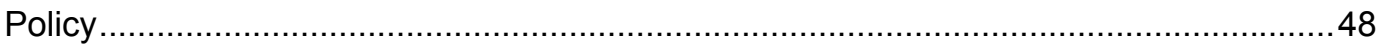

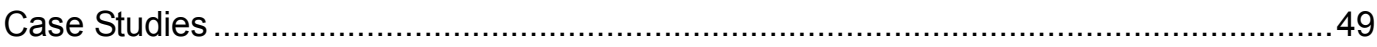

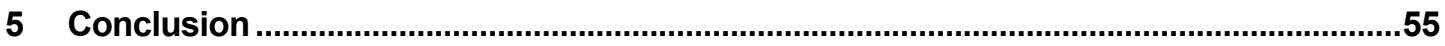

CERL Distribution ....................................................................................................58

Report Documentation Page ...........................................................................................59 



\section{Introduction}

\section{Background}

Army installations must "sustain" their own existence in the context of surrounding civilian communities, the environment, and the Army as a whole. "Unsustainable" installations face a number of risks, including closure. Installations compete for limited resources, such as land or water, with surrounding communities. Communities that neighbor installations often grow towards the installation's borders. Consequently, if the installation has not actively implemented sustainable practices, its perceived value to the community as an economic good neighbor, or military protector might be outweighed by its value as a source of valuable land (or other resources), or by its perception as an environmental (or noise) polluter. Army installations must also conform to the same environmental regulations as their civilian neighbors across the fence. Noncompliance with environmental regulations leads to monetary fines as well as to the image of the installation as an inconsiderate neighbor. In a broad context, installations also compete against each other for their very existence as the Army of the future trims real estate.

Still, "sustainability" is not yet a clearly defined concept. Army installations are just now beginning to develop objective indicators of sustainability, and they have no clear path to achieve sustainability. There is a need to define what is meant by a "sustainable Army installation," to identify indicators of sustainability, and to identify ways to achieve sustainability that will enhance military installations' survivability and competitiveness as a platform for accomplishing the Army mission.

\section{Objectives}

The overall objective of this study is to identify and apply indices of sustainability for the Army installation. The objective of this preliminary part of the study was to summarize past and current research in the area of sustainability indices. 


\section{Approach}

During fiscal year 2001, efforts concentrated primarily on gathering information from previous research into indices of sustainability. A literature search was conducted using the computerized index of the University of Illinois at UrbanaChampaign, the Internet, and recommendations from experts in the fields of sustainability, planning, and modeling. Useful references were compiled in an annotated bibliography of citations and synopses (included in this report). Additional work included development of a preliminary Stella model (to be addressed in a separate technical report).

\section{Mode of Technology Transfer}

The results of this preliminary effort will be incorporated into further work to determine indicators of sustainability, indices of sustainability, and ultimately, a working dynamic systems modeling framework that Army installation planners and policy makers can use to measure and maintain installation sustainability. 


\section{Overview of Sustainable Indices Issues}

\section{Introduction}

Sustainability became an issue of wide public concern and international debate during the 1980s. The terms "sustainability" and "sustainable development" have thus entered the vernacular. "Sustainability" is a buzzword for environmentalists and politicians alike. It is difficult to define since it is used as an umbrella for nearly every environmental issue. It is simplest to define sustainability in terms of what it is not. Global indicators of non-sustainability include global warming, soil degradation, deforestation, species extinction, declining fisheries, and economic inequity.

For millennia, mankind has consumed an increasing share of the earth's natural resources. The current global economy thrives on massive resource use, generating large amounts of pollutants, and disrupting natural cycles. Population growth and increased use of resources place increasingly unsustainable burdens on the environment.

There are many examples of how our lifestyles are depleting natural resources. During the past century we have cut down much of our virgin forests, and filled or drained more than half of the world's wetlands. Worldwide per capita consumption of energy and materials increased over the past 40 years. Reliance on nonrenewable resources causes competition between users and damage to the environment. Substances are discarded into the environment at a rate much higher than they can be absorbed. Annual carbon emissions from fossil-fuel combustion quadrupled over the past half-century, altering the chemical makeup of the atmosphere and leading to global climate change. Water quality worldwide is imperiled by excess nutrients from agriculture as well as a range of other sources that dump nitrates, pesticides, petrochemicals, arsenic, chlorinated solvents, and radioactive wastes into surface waters and aquifers. Development patterns-paving over habitat, designing unwalkable cities, and creating a separation of neighbors-are environmentally and socially destructive. The disparity between the richest and poorest in the world doubled in the last 40 years (Worldwatch Institute 2001).

In the United States, between 1960 and 1990, the amount of developed land in metropolitan areas more than doubled, while the population grew by less than half. The Unites States lost an average of 400,000 acres of "prime" farmland to develop- 
ment each year. This is equivalent to 45.7 acres per hour (Benfield, Raimi et al. 1999).

The United Nations placed a spotlight on sustainability at the global scale. Sustainability is addressed on every level of governance-local, state, regional, national, and international. The concept of building "green" is closely allied with sustainability and the White House and National Parks have been "greened." In the United States, the degradation of city centers, associated suburban sprawl, and the loss of wildlife habitat are all issues that fall under the sustainability umbrella. Despite much effort on all levels, however, there has been no consensus in developing a common concept of sustainability and the means to assess it. The Army community is interested in installations' sustainability as it directly impacts the ability to accomplish the military mission.

Once a group of stakeholders defines the concept of sustainability for an effort, they must develop some means of evaluation. It makes a great deal of difference what is measured, because what we measure is what we pay attention to. The process of measuring focuses attention on the impact of each action. Ranks, ratings, and scores are used to provide an indication of "where we have been and where we are going." They may also be used to compare sustainability between different communities.

Indicators are widely used as a tool for monitoring trends and progress, and are designed to simplify, quantify, and communicate complex issues. The SDI Group defines an indicator as "various statistical values that collectively measure the capacity to meet present and future needs" (SDI Group 2001). Strictly speaking, an indicator is a warning of conditions or problems (Alberti 1996). A good indicator alerts you to a problem before it gets too bad and helps you recognize what needs to be done to fix the problem (Sustainable Measures 1999). Most indicators are simplifications of extremely complex phenomena. In this way they are summary measures.

Sustainability indicators are not just a collection of environmental, economic, and social indicators. The defining characteristic of sustainability indicators is that they show linkages between domains. Environmental indicators look at the effects of human activities on the environment as well as the implications of those actions on human health, quality of life, and the integrity of ecosystems. Economic indicators show how current economic conditions are linked to social and environmental issues. Social indicators measure social well-being and quality of life. 
Traditional indicators such as inflation and unemployment are used for making development decisions, though widely acknowledged to be inadequate as sustainable measures because they fail to address environmental and social consequences.

An important characteristic of sustainability indicators is how they are developed. The idea of indicator development as a group effort is widely held. Each member of a multi-stakeholder team gains a common understanding of what success means to the other members. Involving a wide range of people in the development process is important for stimulating debate and increasing ownership of the indicators. Diverse stakeholders will agree on basic indicators of progress e.g., that reducing pollution, reducing energy use, and increasing employment rates are desirable steps toward a more sustainable community.

There is much discussion and disagreement about who should develop indicators. The options range from international groups of technical and subject matter experts to citizen-centered volunteer efforts. Some believe that a standard set of indicators should be available for anyone desiring an assessment of sustainability. Others believe that indicators are unique to each user group, geographic area, and political entity and will not be taken seriously unless derived locally.

Several organizations have developed lists of indicators, some with the intent that one size fits all, others with the intent that local jurisdictions may pick and choose those that are appropriate. A medium can be achieved if the final definition of target indicator values is determined locally and the community has defined its goals, desires, and expected results from measuring sustainability.

\section{Sustainable Army Installations}

Indices of sustainability are important to the military audience for many of the same reasons they are important outside the fence line. Installations rely on limited resources. Competition for finite resources between military and civilian entities provides an incentive for the military installation to increase its sustainability as a way to meet its own needs, while allowing its civilian neighbors to meet theirs.

The most obvious limited resource is land. Military installations were often established at a time when their locations were far from developed areas. Over time, cities, and urban areas have grown up to the fence line, limiting the buffer areas necessary for the installation to conduct mission activities. Consequently, military installations come into direct competition with the surrounding community for land resources, and also for such resources as water, energy, and even roads, where the impact of shared roads can be a hindrance for both military and civilian users. 
Other "limited resources" may include certain services such as sanitary waste treatment (limited by sewage plant capacity) and solid waste disposal (limited by available land fill space). Such limited resources can become very expensive, and may even become unavailable at any cost.

Regulatory compliance has been an important issue for the Department of Defense for the past decade. Installations must comply with many of the same environmental regulations as their civilian neighbors. Noncompliance can result in heavy fines. This can be seen primarily in the area of hazardous waste disposal, but is also an issue with military owned and operated sanitary and water treatment facilities, and with protecting endangered species habitat.

Installations not in compliance with codes could face additional pressures to close, whether from the surrounding region or in competition with installations that can meet regulatory limits. Historically, noncompliance with environmental regulations has been used to justify the closure of installations deemed too difficult to retain, and ultimately, to make the land and facilities available to private owners.

A set of well-developed indices of sustainability can be an important tool to help installations maintain regulatory compliance. Many of the indices measure the impact of land use on environmental quality e.g., air, water, land, flora, and fauna, while others relate to issues such as standards of efficient energy.

Community relations are also an important consideration for military installations. Future base closings will likely examine both the regional resource constraints and the "nuisance" factor of military installations in a regional context. Military missions that generate dust, noise, traffic or other undesirable side effects that cannot be buffered from the surrounding community may be at risk. Often, there must be a "value added" associated with military installations in urban areas to justify their use of resources in competition with the private sector.

\section{Definitions and Concepts of Sustainability}

There is little consensus on a single, common definition of the term "sustainability"; "sustainability," and "sustainable development" have nearly as many definitions as there are groups that use the terms. However, while no single definition applies equally in all communities, most definitions share a common recognition of the relationships between economy, society, and environment. These definitions express a common concept of "living within the limits of the earth" — as well as anticipating and managing consequences of development. Attention is paid to equitable distri- 
bution of resources and opportunities both inter- and intra-nationally (Sustainable Measures 1999).

The term sustainability is used extensively and can refer to arenas of manufacturing, food and agriculture, and human health. Some efforts slip into the social science arena-encompassing a range of social, cultural, and even spiritual values. Such efforts are considered a holistic view of urban sustainability. Other evaluative efforts include "healthy city" and "quality of life" indicators (Maclaren 1996).

The UN World Commission on the Environment and Development (commonly known as the Brundtland Commission) pioneered the term "sustainable development." The 1987 Brundtland Commission Report defined sustainable development as "development that meets the needs of the present without compromising the ability of future generations to meet their own needs" (World Commission on Environment and Development 1987).

The 1992 United Nations Conference on Environment and Development (UNCED), better known as the "Earth Summit," was held in Rio de Janeiro, Brazil. Over 170 countries cooperated in this conference to produce treaties on climate change and biological diversity, a set of forestry principles, and an extensive plan for sustainable development into the $21^{\text {st }}$ century called Agenda 21. Agenda 21 includes a proposal to develop indicators for sustainable development. The objective is to make indicators accessible worldwide to decisionmakers at the national level by defining sustainability indicators, explaining their methodologies, and providing training and other capacity-building activities. Principle 1 of Annex I, "The Rio Declaration on Environment and Development," declares that "Human beings are at the center of concerns for sustainable development. They are entitled to a healthy and productive life in harmony with nature" (UNCED 3-14 June 1992).

The interpretation of the term sustainability drives the selection of indicators. The existence of so many definitions highlights the value-laden qualities of sustainability. Some characteristics have been accepted universally, while others are more controversial and may not be adopted by all communities (Maclaren 1996).

"Natural Capital" is a term often associated with sustainability efforts. The term capital is most commonly used to refer to money and material goods. In the context of sustainability, communities have several different types of capital that need to be considered. Sustainable Measures uses the term Community Capital to refer to the "natural, human, social, and built capital from which a community receives benefits and on which the community relies for continued existence." All four types of Community Capital are necessary for communities to function, and therefore need to be managed. 
Carrying capacity is the size of population that can be supported indefinitely on the available resources and services of an ecosystem. Living within the limits of an ecosystem depends on the amount of resources available, the size of the population and the resources each individual is using. A community that is living on the interest of its community capital is living within its carrying capacity. In the context of sustainability, carrying capacity is the size of population that can be supported indefinitely on the available resources and services of supporting natural, social, human, and built capital (Sustainable Measures 1999).

Urban regions "consume" more land than they contain within theirs political boundaries. Urban regions meet their needs by "appropriating" carrying capacity from other regions. They also appropriate carrying capacity from the past (e.g., fossil fuel) and from the future (e.g., badly eroded land that is no longer productive) (Wackernagel and Rees 1996). The magnitude of an urban economy's appropriated carrying capacity (ACC) is a measure of the size of its ecological footprint.

Examining sustainability requires considering the ecosystem as a set of complex and interconnected dynamic systems. Environmental Assessment (EA) historically identified conditions and trends, though did not always identify causal links. It is important to understand feedback mechanisms in the indicator development process, particularly where indicators will drive policy decisions. A sustainability report should consider impacts outside of the community, answering the question, "Are we going to be better off by making someone else worse off?"

\section{Measuring: Sustainability Indicators}

Once a group of stakeholders defines the concept of sustainability for an effort, it must develop some means of evaluation. It makes a great deal of difference what is measured, because what we measure is what we pay attention to. The process of measuring focuses attention on the impact of each action.

The specific thing we measure is called an indicator. An indicator is a piece of information that reflects what is happening in a larger system. It allows observers to see the big picture by looking at a smaller part of it. Indicators are often quantitative measures such as physical or economic data.

Developing a set of indicators involves balancing many different needs within a community. An initial list of indicators may number in the hundreds. A final list needs to be developed based on local criteria. The right number of indicators will depend on the type of audience for the indicator report, the time required to obtain data, the number of issues involved, and the special needs of the community. 
A framework for developing a set of indicators is necessary for every indicator effort. The choice of framework must meet the needs and priorities of users. A number of frameworks have been identified and used. These include domain-based, goalbased, sectoral, causal, issue-based, and combination frameworks. Other types of frameworks - such as condition-stress-response and pressure-state-response- -build off the basic frameworks. These frameworks can provide a starting point for any organization embarking on a sustainability effort.

There are disagreements regarding which data is required (or should be used) to select an indicator. Many believe that indicators should be readily measurable and based on existing sources of information that the public accepts as reliable. This allows the numbers to be freely checked and avoids debate on whether they are correct. For this reason, many communities choose traditional data sources for indicators (Environmental Defense 1999).

The number of indicators selected varies tremendously among separate efforts. More specifically, an effort to select appropriate indicators for a sustainable environmental effort, e.g., sustainable training area, would be far more complex (involve many more indicators) than an effort to select indicators for an issue with much smaller scope, e.g., sustainable parking lot lighting. Using a large number of indicators allows a greater level of detail, but risks the loss of coherency for an overall rating. Using a small number of indicators can eliminate entire individual areas of great interest. The number of indicators chosen is unique to each indicator effort. The correct number of indicators for a given effort depends on the audience for the report, the time available to research data, the number of issues involved, and the special needs of the community.

Sustainable development indicators must be able to show problem areas quickly and clearly to decisionmakers. This is vital in the case of highly aggregated indices. Two main thrusts emerge: (1) determining the type of measure used to show an indicator's status, and (2) creating an effective presentation of indicators.

Two or more indicators combined mathematically are called an index. Indices greatly simplify the complex information found in the index's component parts to often just one number. Some common examples of indexes (outside the subject of sustainability) are the Consumer Price Index, which combines the prices of a sample of goods and services commonly bought to compare the average price of goods from one year to another; and the Dow-Jones Industrial Average, which reflects the changes in market prices of 30 blue-chip stocks listed on the New York Stock Exchange (International Institute for Sustainable Development 2000). 
Several problems can occur with the aggregation of indicators. A decision must be made on how to weight indicators. If an index lacks important pieces of information, or improperly represents information, it can give decisionmakers a false signal. Another issue in standardizing indicators is that distinct indicators are often expressed in different units. Once successfully integrated, indices are also less transparent than their component indicators. 


\section{Modeling}

In its current usage, the notion of sustainability invokes the underlying assumption of a dynamic systems modeling framework. In an "environmentally sustainable economic development," something is held constant while something else is allowed to change. The term captures a sense of tension (of balanced or unbalanced elements), i.e., economic growth, environmental protection, and social equity. Scott Campbell's (1996) piece on planning traditions and the conflicts of sustainable design discusses strategies for operationalizing the sustainable ideal. He notes that, "planners need better tools to understand their cities and regions not just as economic systems, or as static inventories of natural recourses, but also as environmental systems that are part of regional and global networks ..." This implies the use of large scale "dynamic modeling" techniques to realize the environmental implications of planning actions.

Some sources described in this bibliography argue in favor of dynamic (spatial) models to inform the process of societal change and establish causal relationships have been made (Costanza and Maxwell 1991; Forrester 1969; Hannon and Ruth 1994; Ruth and Hannon 1997; Sklar and Costanza 1991). More specifically, modeling can provide assistance in managing uncertainty, feedbacks and lags, group decisionmaking, and comprehensive learning (e.g., authentic tasks, cognitive apprenticeship). The benefits of models and model development are that they can:

- increase awareness in the understanding of fundamental systems processes (It identifies the most important parameters in the system.)

- provide a system memory

- reveal "normal" system performance

- allow testing of "what-if?" scenarios (experimentation)

- provide quantitative results.

The process of modeling can also facilitate communication (through both model results and structure) to reveal possible emergent properties of a system. Operationalizing any system requires an approach similar to the modeling framework discussed here. Operationalizing the sustainability question is discussed here within this framework. 
The development of dynamic models requires:

- identification of the necessary tools (programming basics, the physical and economic principles)

- definition of the problem and the model objectives (stating the precise questions to be answered with the model)

- identification of the performance measures (physical or economic)

- review of analogs for the model development (reference to similar work)

- identification of the states, flows, parameters, controls, constraints

- minimal model development, including:

- calibration, validation, and revision of this model

- identification of impacts of feedbacks, lags, and uncertainty on the designated performance measure (sensitivity analysis)

- performance measure optimization of the model (techniques, interpreting variable answers)

- the extension of the model (answering deeper or different objectives).

One of the key components to model development is the identification of controls, states, flows, and parameters. Controls strategies are important for providing a quantitative basis for management decisions (the operationalization of the model) (Engelen, White, and Uljee 1997). The instruments of control (both indigenous and endogenous to the model) set the criteria for model utility.

Several guidelines can be used to develop the criteria and methodology for determining the control strategies on the impacts and indices of sustainability. Hardi (1997) presented three criteria to assist sustainable indicator development initiatives: (1) stakeholder participation, (2) coverage of ecological and socio-economic dimensions, and (3) establishment of formal protocols (Hardi 1997). Campbell (1996) presented a triangular structure (alluded to above) for the development of quantifiable sustainability criteria. The points of the triangle represent: (1) socially oriented goals, (2) economic goals, and (3) environmental impacts. Herendeen (1998) used destruction, dependence, and depletion of resources (Herendeen 1998; Campbell 1996). Processes and criteria are then assigned scales of influence within the structure for evaluation against the whole.

The incorporation of dynamic systems modeling techniques can assist in efforts to operationalize sustainability and to develop indicators of sustainability. Sustainability is a goal, not a defined place or space. The vagueness of defining sustainability is permissible in this context, because the goal will be to redefine the term many times in the quest to achieve a concise terminology. This method for validating a sustainable approach will use the best science to implement models of societal reformation and behavioral modification to affect change. It will use the lessons 
learned from these models and their implementation to improve itself through subsequent iterations.

The overall objective is to improve the viability of the built human system to include a sustainable future by creating models and solutions that can affect change, improve our basic understanding of the human/ecology interface, and that also provide feedback for the next (improved) generation of models and solutions. 


\section{Annotated Bibliography}

The annotated bibliography is divided into eight sections: Sustainability, Ecology/Environment, Social/Economic, Indicator Development, Modeling, Planning, Policy, and Case Studies.

\section{Sustainability}

\section{Alberti, M., "Measuring Urban Sustainability," Environmental Impact Assessment Review, vol 16, No. 4-6 (1996), pp 381-427.}

The author believes that conventional measures of economic performance and urban quality of life do not capture the interdependence between urban society, economic development, and the environment. This article examines various dimensions of urban sustainability, including discussions of natural capital and carrying capacity. The article stresses the importance of developing linkages between urban patterns and the natural resource base, and analyzes different approaches for designing urban indicators both at the international (UNCHS, World Bank, UNCDS, OECD, EEA and WHO) and at the local level. Finally, the article recommends a process for selecting indicators to ensure the data used is relevant, scientifically founded, implementable, and usable for planning.

\section{Benfield, F.K., M.D. Raimi, et al., Once There Were Greenfields: How Urban Sprawl Is Undermining America's Environment, Economy, and Social Fabric (New York, Natural Resources Defense Council, 1999).}

This book describes suburban sprawl and suggests alternatives to uncontrolled growth. The authors document suburban growth trends in the United States as a whole as well as regional examples. The Chicago case study presented is used to show how sprawl occurs and, more importantly, why it occurs. Negative environmental effects of sprawl include increased auto traffic, higher consumption of energy, and generation of byproducts of fossil fuel combustion, loss of open space (including farmland and wildlife habitat), and increased amounts of polluted storm water runoff. Other negative effects of sprawl documented in this book are the economic cost and the social costs. The authors conclude on a positive note describing guiding principles for nonsprawling land use. They describe three real-world models 
of successful smart growth: Portland, Maryland, and the European experience.

Billingsley, L., "Facts Versus Fantasy on Urban Sprawl” (Pacific Research Institute for Public Policy, 1999), available through URL:

http:// www.pacificresearch.org/action/action17.html

This essay claims that urban sprawl is more fantasy than reality. The author claims that sprawl actually only consumes a small fraction of land in the United States. The author also claims that smart growth boundaries create exclusionary situations where housing prices rise at rates much faster than the national average.

Center of Excellence for Sustainable Development, The Energy Yardstick: Using PLACE ${ }^{3}$ S To Create More Sustainable Communities, No. 159 (Office of Energy Efficiency and Renewable Energy, U.S. Department of Energy, 1997).

PLACE ${ }^{3} \mathrm{~S}$ is an acronym for PLAnning for Community Energy, Economic, and Environmental Sustainability. It is a land-use and urban design method to show the linkage between growth and development decisions, and sustainability. This system uses energy to evaluate the efficiency of landuse, neighborhood and transportation planning, and operation of buildings and public infrastructure. $\mathrm{PLACE}^{3} \mathrm{~S}$ is appropriate for local or regional analysis. The five-step process is to: (1) document existing conditions, (2) project existing conditions out to the planning horizon, (3) develop and analyze more efficient alternatives, (4) create a preferred alternative, and (5) adopt the preferred alternative. The PLACE ${ }^{3} \mathrm{~S}$ manual includes many case studies.

\section{Energy Efficiency and Renewable Energy Network (Center of Excellence for Sustainable Development, 2001), available through URL: http://www.sustainable.doe.gov}

This U.S. Department of Energy web site is a comprehensive source on sustainable development. It provides a range of definitions from many sources. This site contains links to other sites containing sustainable development principles (Wingspread, Hannover, Natural Step, Earth Charter Benchmark, Precautionary Principle, National Park Service, Ontario Roundtable, Clinton-Gore Livability Agenda). It describes success stories and has links to many resources e.g., codes, ordinances, articles, publications, educational materials. 


\section{U.S. Environmental Protection Agency, Green Communities: Where Are We Now? (USEPA - Region III, 2000).}

This reference provides guidelines for taking stock of a community's social, economic, and environmental assets to help identify what is working and what needs to be improved. The process is divided into four phases: where are we now?, where are we going?, where do we want to be?, and how do we get there? The web site examines several case studies, and includes tools and resources. This web site espouses Maclaren's indicator frameworks (domain-based, goal-based, sectoral, issue, causal, and combination). Examples of indicators are given along with a process for selecting indicators. This site links to other web sites on indicators, data sources, and references.

Furtado, J.I. d. R., T. Belt, et al., Economic Development and Environmental Sustainability (The International Bank for Reconstruction, Washington, DC, 2000).

This book explores a broad range of practical issues related to environmental management, including wealth creation, institutions, equity, energy, trade, human health, and ecological sustainability. Economic Development and Environmental Sustainability was developed as part of a 5-year program of policy seminars on economic development and environmental management, as well as economic globalization and environmental sustainability. The seminars were held in several regions including Southeast Asia, Eastern Europe, and Central Asia. The seminars were conducted by the World Bank Institute, in collaboration with the Foundation for Advanced Studies on International Development in Japan, and with the support of the governments of Japan and the Netherlands. This book is intended for decisionmakers, policy analysts, representatives of nongovernmental organizations, and all those interested in understanding and contributing to environmentally sustainable development.

\section{Global Ecovillage Network, "Community Sustainability Assessment" (2001), available} through URL:

http://www.gaia.org/secretariats/international/projects/csrareviewgroup/English/ind ex.html

This web site is maintained by the Global Ecovillage Network (GEN). GEN is a grassroots nonprofit organization that links together ecovillages and related projects around the world. GEN promotes and supports models of sustainable living globally, to inspire and encourage the creation of more viable lifestyles on this Earth. This site describes an evaluation process called the Community Sustainability Assessment. It is a comprehensive checklist that provides a basic idea of how sustainable a community is. This assessment tool is intended to be applicable to any community. While it requires good 
knowledge of the life-styles, practices and features of the community, it does not require research, calculation and detailed quantification. This assessment takes about 2 to 3 hours for an individual to complete, or several times that if done by a group of community members. The assessment is intended to be mailed in to a regional office. (The Ecovillage Network of the Americas is in Colorado.) The site also describes the Ecovillage Audit, an in-depth evaluation instrument that requires the gathering and computation of empirical data. This audit is intended to reflect the actual/objective results of the community's commitment to sustainability. Another tool described here is the Personal Sustainability Questionnaire. At Habitat II, the U.N. Conference on Human Settlements in Istanbul (1996), GEN presented a large exhibit on ecovillages and aspects of sustainable living. One part of the exhibit involved a sustainability self-audit evaluating personal lifestyle at the level of the individual household. This tool is in revision.

\section{Hannon, B., M. Ruth, et al. "A Physical View of Sustainability," Ecological Economics, vol 8 (1993), pp 253-268.}

This article proposes a definition of sustainability based on physically measurable evidence. Since fossil fuels are consumed much faster than they are being formed, a social structure based on their extensive use cannot therefore be sustainable. What type of social structure does meet our definition of sustainability? That is, what style and size of social activity will generate entropy at a rate no greater than that of the climax ecosystem in a particular area? During the last two decades, studies of economic activities and their environmental repercussions were limited to the possible cost and benefits of pollution control, and to the economically optimal extraction rates of mineral resources. The intrusion of human activities into the environment became increasingly apparent through the depletion of natural resource stocks and decreasing environmental quality. Although research is increasingly concerned with the question of sustainability, a definition based on physically measurable evidence is missing. This paper proposes such a definition and gives an example application for a particular area.

Hardin, Garrett, "The Tragedy of the Commons," Science, vol 162 (1968), pp 1243-1248.

This article deals with the population explosion and the concept of carrying capacity. The author expresses the viewpoint that the solution to the population problem cannot be found in technical innovation, but instead in values. Hardin argues that Bentham's utilitarian ideal, the maximum good for the maximum amount of people is unattainable. The solution offered by Hardin is one of mutual coercion by recognition of necessity. The tragedy of the commons develops in this way: 
Imagine that everyone has access to a common resource. As a rational being, each person seeks to maximize his/her gain. Everybody asks themselves, "What is the utility to me of consuming one extra unit of this resource?" This utility has one negative and one positive component. Individual rational consumption leads to the ruin of the common resource because their collective behavior is unsustainable.

Imbach, A., E. Dudley, et al., Participatory and Reflective Analytical Mapping for Sustainability (PRAM), vol 44 (Cambridge, International Union for the Conservation of Nature and Natural Resources, 1997).

This is the first in a series of eight volumes developed by a cross-disciplinary team for people interested in assessing progress toward sustainability. The four steps to understanding sustainable and equitable development are treating people as an inextricable part of the ecosystem (people and the environment are equally important), asking questions (knowing which questions to ask and their context), reflective institutions (groups of people coming together to question and learn collectively), and being people-focused (people are both the problem and the solution). This report describes the Participatory and Reflective Analytical Mapping (PRAM) method. PRAM was devised for the assessment of unplanned processes. The four main components of PRAM are: the institution and its decisionmakers, the context in which the institution operates, the social actors who interact among themselves and with the institution, and the monitoring and evaluation process. The report outlines the conceptual base of PRAM and describes the process of using the PRAM method. The last section presents examples of the application of PRAM.

\section{National Park Service, Guiding Principles of Sustainable Design, vol 117 (Denver, U.S. Department of the Interior, 1993).}

This report provides guidance for achieving sustainability in facility planning and design in U.S. national parks and conservation areas. The report begins by listing indicators of environmental degradation at the hands of mankind. It defines sustainability as the capability of natural and cultural systems to maintain themselves over time. It refers to the "Hannover Principles" or "Bill of Rights for the Planet" developed by William McDonough Architects for EXPO 2000 in Hannover, Germany. The principles suggested for design and management of parks emphasize environmental sensitivity, use of nontoxic materials and integration of visitors with natural and cultural settings. The report is divided into nine topics: interpretation, natural resources, cultural resources, site design, building design, energy management, water supply, waste prevention, and facility maintenance and opera- 
tions. It contains detailed design information that is enhanced with line drawings.

Ryn, S.V., and P. Calthorpe, Sustainable Communities: A New Design Synthesis for Cities, Suburbs and Towns (Sierra Club Books, San Francisco, 1986).

This book is a primer for building in a sustainable fashion. By employing methods found in the text, the use of fossil fuels can be sharply cut, and economies are in balance with what the region can supply through natural processes. The essays in this volume are the outgrowth of a "Solar Cities Design" workshop. Contributors include architects, community planners, ecologists and biologists. Case studies demonstrating how human-scale communities could be built range from the undeveloped Chino Hills near Los Angeles to Philadelphia's gentrified neighborhoods. Essays fault agribusiness for its massive waste of land, energy, and human resources, and call for smaller, more fuel-efficient cars. This book offers innovative solutions to the renewal of communities.

Ryn, S.V., and S. Cowan, Ecological Design (Island Press Washington DC, 1996).

This book advances the premise that we must infuse the design of products, buildings, and landscapes with a rich and detailed understanding of ecology to create a sustainable world. The authors see our present forms of agriculture, architecture, engineering, and technology as deeply flawed. Sustainability "needs to be firmly grounded in the nitty-gritty details of design." Professionals from different but related disciplines must start communicating with each other to implement good design. The text presents an overview of ecological design, sets forth the five basic principles of ecological design, and concludes with an extensive resource guide and bibliography.

\section{Solstice: Sustainable Energy and Development Online (Center for Renewable Energy and Sustainable Technology [CREST]), available through URL: http://sol.crest.org/}

This site offers extensive research that has been done on renewable energy, energy efficiency, and sustainable living. It offers up to date reports on related news and links to related sites, and discussion groups.

\section{UNCED, Report of the United Nations Conference on Environment and Development} (Rio de Janeiro, 1992).

The United Nations Conference on Environment and Development met at Rio de Janeiro from 3 to 14 June 1992, reaffirming and seeking to build on the Declaration of the United Nations Conference on the Human Environ- 
ment, adopted at Stockholm on 16 June 1972. The conference set goals of establishing a new and equitable global partnership through the creation of new levels of cooperation among states and key sectors of societies and people, working towards international agreements that respect the interests of all and protect the integrity of the global environmental, and recognizing the integral and interdependent nature of the Earth. Together, the countries declared that sustainable development to be of prime importance and assured each other of mutual cooperation in implementing sustainable practices.

Wackernagel, M., and W.E. Rees, Our Ecological Footprint: Reducing Human Impact on the Earth (New Society Publishers, British Columbia, Canada, 1996).

This book synthesizes discussions of sustainability, carrying capacity, resource use, and waste disposal, and formulates a new way to graphically measure the human impact on the environment: the Ecological Footprint. The Ecological Footprint is a measure of the load imposed by a given population on nature. It represents the land area necessary to sustain current levels of resource consumption and waste discharge by that population. The average North American Footprint is equal to three city blocks. If everyone on the planet consumed at that rate, it would take two additional planets to provide the necessary natural resources.

\section{Walter, B., L. Arkin, et al., Sustainable Cities: Concepts and Strategies for Eco-City Development (Eco-Home Media, Los Angeles1992).}

The book examines the components of good ecological city design with an overarching emphasis on sustainability. It examines ecological design components such as solar design, water management, urban landscape, waste management, transportation, sustainable technologies, and economic stress.

\section{World Commission on Environment and Development, Our Common Future (Oxford University Press, New York, 1987).}

The World Commission on Environment and Development, headed by Gro Harlem Brundtland, Prime Minister of Norway, was set up in 1983 by the United Nations. Its task was to re-examine the environmental and development problems on the planet, and to formulate realistic proposals to solve them. It set out to ensure that human progress will be sustained through development without bankrupting the resources of future generations. The major idea to come from this commission was a definition of sustainability: an approach to progress that meets the needs of the present without compromising the ability of future generations to meet their own needs. 


\section{Ecology/Environment}

\section{Costanza, R., ed., Ecological Economics: The Science and Management of Sustainability (Columbia University Press, New York, 1991).}

This book contains 32 chapters of essays exploring the subject of ecological economics. Ecological economics is an approach to understanding and managing the ecology and economics of our world for sustainability on local, regional, and global scales. The book advances the notion that the isolation of these disciplines has led to economic and environmental policies that are mutually destructive. The essays in the text attempt to bring these two disciplines together, discussing the fundamentals of ecological economics; accounting, modeling, and analysis of ecological economics systems; and necessary institutional changes and case studies.

\section{Environmental Defense, Environmental Sustainability Kit (Environmental Defense, New York, 1999).}

The Environmental Sustainability Kit is a set of tools that includes ideas, procedures, and resources to help local leaders, residents, and businesses work toward making their own communities more sustainable. These tools focus on the environmental and pollution prevention aspects of sustainable communities efforts. This web site contains information on defining sustainability, the consensus-building process, indicators of progress, case studies and resources. Environmental Defense is a New York-based, private, nonprofit research and advocacy organization with over 300,000 members nationwide. The staff of Environmental Defense includes scientists, engineers, attorneys, and economists who seek solutions to a broad range of environmental and human health problems.

\section{Environmental Protection Agency, Latest Findings of National Air Quality: 1997 Status and Trends, vol 19 (Office of Air Quality Planning and Standards, Triangle Park, 1998).}

This brochure highlights the EPA's evaluation of status and trends in U.S. air quality. It identifies national air quality standards for carbon monoxide, lead, nitrogen dioxide, ozone, particulate matter, and sulfur dioxide. The EPA tracks air concentration at selected monitoring sites throughout the country. Emissions are also tracked based on engineering estimates of the total tonnage released into the air annually. This report evaluates the six principal pollutants. It also contains sections on acid rain, visibility, toxic air pollutants, and stratospheric ozone. 


\section{Hannon, B., "Accounting in Ecological Systems, Ecological Economics: The Science and Management of Sustainability," in Costanza, Ecological Economics (Columbia University Press, 1991), pp 234-252.}

This essay proposes the use of an ecological accounting system that incorporates the connections between materials, energy, and service flows. Previously, ecological accounting systems treated these flows independently. This essay advances a general accounting framework that addresses these deficiencies, and develops a system of weights for the units of the flows. The system integrates data collections that were previously independent into a common framework to amplify their original usefulness.

Herendeen, R., Ecological Numeracy: Quantitative Analysis of Environmental Issues (John Wiley \& Sons, Inc., New York, 1998).

This book is based on a course taught to upper level undergraduates and beginning graduate students in ecology, planning, geography, natural resources, and engineering at the University of Illinois at Urbana-Champaign. It is intended to help develop quantitative environmental skills necessary to identify the ecological issue at hand and argue a point forcefully to diverse audiences. A down-to-earth problem solving approach is applied to a wide range of environmental issues, including resource depletion, greenhouse gas production and removal, energy forecasting, population dynamics, competitive exploitation of common resources, transportation planning, and sustainable economics. Methods covered include relative magnitudes, rates of change, multiplier effects, lead times, lag effects, ecological limits, life-cycle costs, and least cost ways of doing things. Many numerical examples are featured.

\section{Myers, N., R.A. Mittermeier, et al., "Biodiversity Hotspots for Conservation Priorities,"} Nature, vol 403 (2000), pp 853-858.

The authors address how conservationists can support the most species at the least cost. They identify "hotspots," areas with concentrations of endemic species that are experiencing severe loss of habitat. Each hotspot has boundaries that describe a biogeographic unit. To qualify as a hotspot an area must have at least 0.5 percent of the world's plant species as endemics. It must also meet a "degree of threat" criterion through loss of at least 70 percent of its habitat. This methodology resulted in identification of 25 hotspots that together contain 44 percent of the world's plant species and 35 percent of its vertebrate species. These areas comprise 1.4 percent of the Earth's land surface, having already lost 88 percent of their primary vegetation. If present rates of extinction continue, between one-third and twothirds of all species will likely disappear in the foreseeable future. The au- 
thors contend that this mass extinction can be prevented through protection of the 25 hotspots. They recommend safeguarding of the hotspots at a cost of $\$ 20$ million each over the next 5 years for a total of $\$ 500$ million annually.

\section{Orr, D.W., Ecological Literacy: Education and the Transition to a Postmodern World (State University of New York Press, Albany, NY, 1992).}

This book attempts to define the scope and depth of the crisis of sustainability. The book advances the hypothesis that unsustainable development practices are deeply seeded in fundamental assumptions about science, human nature, politics, the economy, competition, and institutions. A reformed education system that ensures ecological literacy is seen as an essential part of the solution to the environmental crisis. The text proposes that education makes students ecologically literate by acquainting them with the deeper causes of the environmental crisis and promoting ecological competence. The goal of the proposed educational model is an active, engaged citizenry committed to the common good.

\section{Orr, D.W., Earth in Mind: On Education, Environment, and the Human Prospect (Island Press New York, 1994).}

This book examines the fundamentals of good design and promotes ecological design competence as the highest ideal. Orr defines ecological competence as maximizing resource and energy efficiency, utilizing nature's free services, recycling, making ecologically smarter things, and educating people. The text fundamentally examines the question, what does it mean to improve education? Orr advances the idea that modern education systems fundamentally fail to achieve any degree of ecological awareness in students, and to the contrary, equips them to become more effective vandals of the earth. The text proposes a major overhauling of the education system to address this paradigm rather than merely adjusting the system. Orr suggests that myths exist in modern education that must be dispelled as part of this process. These myths include the notion that planet earth can be managed by science and technology, that ignorance is a solvable problem, that knowledge is inherently good, that the dismantled can be restored, that the purpose of education is success, and that our culture represents the pinnacle of human achievement. Six principles are proposed to dispel these myths: (1) all education is environmental education, (2) the goal of education is the mastery of one's self, (3) knowledge carries responsibility, (4) it is important to understand the effects of theories on real people and places,

(5) institutions and educators should function as role models, and (6) education should function as active participatory learning. 
Pickett, S.T.A., J. Kolasa, et al., Ecological Understanding (Academic Press, San Diego, 1994).

This book reviews ecological theories and how they are generated, evaluated, and categorized. The authors synthesize a vast literature on the subject and condense it as a useful entry into the scientific philosophy of ecology and natural history.

\section{Rosenzweig, Michael L., "Heeding the Warning in Biodiversity's Basic Law," Science,} vol 284, No. 5412 (1999), pp 276-7.

This article examines the relationship between the size of an ecosystem, and the number and diversity of species that inhabit that system, and focuses on biodiversity's basic law that larger areas harbor more species. The author calls for humans to find gentler ways to occupy land so that the many species that also rely on the same land for survival do not face extinction.

Rowntree, R.H., and P. Muick, The Ecological City: Preserving and Restoring Urban Biodiversity (The University of Massachusetts Press, 1994).

This text is a collection of original essays that take a fresh look at the ecology of urban communities. The essays are divided into several subjects: perspectives on nature in cities, urbanization, and riparian/aquatic systems, urbanization, and terrestrial ecosystems, and collaborative efforts.

Shepherd, A., and L. Ortolano, "Strategic Environmental Assessment for Sustainable Urban Development," Environmental Impact Assessment Review, vol 16, No. 4-6 (1996), pp 321-335.

Strategic Environmental Assessment (SEA) considers the environmental impacts of policies, plans, and programs. The authors state that many countries have implemented SEA as a means of achieving sustainability. This article examines this practice by describing the opportunities for SEA to promote sustainability principles, presenting case studies of cities and countries that have done so, and analyzing SEA's effectiveness and its challenges for sustainable urban development.

Tilman, D., and P. Kareiva, eds., Spatial Ecology: The Role of Space in Population Dynamics and Interspecific Interactions (Princeton University Press, Princeton, NJ, 1997).

This book is a collection of essays that address the fundamental effects of space on the dynamics of individual species and on the structure, dynamics, diversity, and stability of multispecies communities. The essays are divided into four topics: (1) single species dynamics in spatial habitats; (2) parasites, 
pathogens, and predators in a spatially complex world; (3) competition in a spatial world; and (4) how will we test our ideas?

Tilman, D., D. Wedin, et al., "Productivity and Sustainability Influenced by Biodiversity in Grassland Ecosystems," Nature (22 February 1996), p 379.

Describes how a well-replicated field experiment, in which species diversity was directly controlled, showed that ecosystem productivity in 147 grassland plots increased significantly with plant biodiversity. Trying to get more data to support Darwin's proposal that more diverse plant communities are more productive, have lower nutrient losses, and more stable soils.

Wilson, E.O., ed., Biodiversity: National Forum on Biodiversity (National Academy Press Washington, DC, 1988).

This book presents 57 important essays on the current state of Earth's biodiversity. Among issues examined in individual essays are the current mass extinction, destroyed ecosystems, deforestation, current preservation and conservation efforts, and calls to further action.

Wu, J., and O.L. Loucks, Balance of Nature and Modern Ecological Theory: A Shift in Ecological Thinking. Development and Trends in Modern Ecology (Hefei, University Science and Technical Press, Sino-ECO, 1991).

\section{Social/Economics}

Daly, H.E., and J.B. Cobb Jr., For the Common Good: Redirecting the Economy Toward Community, the Environment and a Sustainable Future (Beacon Press, Boston, 1994).

This book addresses the need for a fundamental paradigm shift in the study of economics to create more sustainable communities. The issues this book addresses range from spatial and population dynamics, to models of organisms, genetic movements, and physical systems. The text's main focus is economics. A critique of how economics is taught in today's university structure is outlined, and the authors recommend that more ecological economics be taught to students. The authors propose that economies exist on a more human and manageable scale: a world built on meaningful work in more localized economies. They propose that more emphasis be placed on the microeconomic scale of analysis to build sustainable communities. A discussion takes place of the human prospect itself - whether or not the human race is inherently self-destructive, and if so, how this can be overcome. 


\section{Homer-Dixon, Thomas, and Peter Gizewski, Urban Growth and Violence: Will the Future Resemble the Past? (1995), available through URL: http://www.library.utoronto.ca/pcs/eps/urban/urban1.htm}

This paper examines the many social, economic, and political problems that have accompanied urban growth in the developing world. Will further growth result in violent behavior as expectations of economic improvement and social mobility are dashed? Past theoretical and empirical research on the links between urban growth and violence showed the relationship to be weak to nonexistent. However, these past findings may not apply to present and future urban environments. This paper suggests why the future may differ from the past. In particular, it points to factors that may interact with urban growth in the future to lead to a more violent urban experience. These factors include periodic economic crisis, the reduction of state capacity to cope with political challenges, grassroots demands for democratization, and a gradual fading of the rural experience as a basis for evaluating relative economic standing and opportunity.

\section{Porter, M.E., and C.V.D. Linde, "Green and Competitive: Ending the Stalemate,"} Harvard Business Review, vol 73, No. 5 (1995), pp 120-134.

This article articulates the viewpoint that properly designed environmental standards can encourage innovations in industrial processes that improve product quality or reduce its cost. Enhanced resource productivity makes companies more competitive. This viewpoint encourages manufacturers to recognize the full systems costs and values associated with a product. These include the opportunity costs of pollution-wasted resources, wasted effort, and diminished product value to the customer. Environmental regulation in the United States is a unilateral process that discourages innovation. The author lists criteria for innovation-friendly regulation. In addition to reducing adverse environmental impacts, innovation in response to regulation can minimize the cost of dealing with pollution and improve resource productivity in the first place. Other benefits are improved product consistency and quality, reduced downtime, lower costs, and higher yields. The cost to business of maintaining the status quo is the expenditure of enormous amounts of resources in setting and enforcing environmental regulations. Companies waste energy fighting environmental standards instead of enhancing their competitiveness. The authors illustrate their points with several examples. 


\section{Indicators}

lowa State University, Measuring Community Success and Sustainability (1999), available through URL: http://www.ag.iastate.edu/centers/rdev/Community Success/about.html

This web site contains an interactive workbook developed to help communities learn how to measure the local or regional impacts of economic and community development processes that enhance rural community sustainability. The main purpose is to provide a way for local communities to measure progress toward local goals. Sections include performance based measurement and community building, guidelines for measuring, sample indicators and measures, and sustainable, healthy ecosystems with multiple community benefits.

LaFond, A.A. a. M., Assessing Sustainability Projects: A Prototype Rating System for Comparative Evaluation (AtKisson \& Associates, Inc, Seattle, WA, 1994).

The authors have developed a prototype evaluation system using three rating scales. These scales assess: (1) the extent to which a project incorporates all the major features of sustainability (S-scale), (2) the degree to which the project has been institutionalized (I-scale), and (3) the level of comprehensiveness and integration in the project design (C-scale). These scales are defined and then applied to four case studies, two "sustainable" housing developments (Bamberton, BC, Canada, and Ecolonia, The Netherlands), and two national initiatives to promote sustainable development policy (the U.S. President's "Council on Sustainable Development," and the Netherlands' "National Environmental Policy Plan"). The S-I-C scales are used to compare each set of examples, highlighting their different strengths and weaknesses. This assessment tool is intended to aid in what are inevitably subjective evaluations by providing a consistent structure for analysis. It is also intended to provoke thought about how to improve existing efforts.

\section{Lee-Smith, D., Community-Based Indicators (International Union for Conservation of} Nature and Natural Resources, Cambridge,1997).

This publication is one in a series of eight volumes developed by The International Union for Conservation of Nature and Natural Resources (IUCN) to assist in assessing progress toward sustainability. It deals with how to develop indicators for assessing communities' strategies. There is a discussion of frameworks available for indicator development. The description of tools for measuring and aggregating indicators covers scales and aggregation methods. Practical examples of indicator development in Zimbabwe are 
shown. The author states that this report is a tool that can be used with any method of system assessment.

Liverman, D.M., R.W. Merideth, Jr., et al., "Global Sustainability: Toward Definition,” Environmental Management, vol 11, No. 6 (1987), pp 713-719.

Sustainability is increasingly viewed as a desired goal of development and environmental management. This term has been used in numerous disciplines and in a variety of contexts, ranging from the concept of maximum sustainable yield in forestry and fisheries management to the vision of a sustainable society with a steady-state economy. The meaning of the term is strongly dependent on the context in which it is applied, and on whether its use is based on a social, economic, or ecological perspective. Sustainability may be defined broadly or narrowly, but a useful definition must specify explicitly the context as well as the temporal and spatial scales being considered.

\section{Maclaren, V., Developing Indicators of Urban Sustainability (Intergovernmental Committee on Urban and Regional Research, Toronto, 1996).}

This report documents the author's six-step process for developing urban sustainability indicators. MacLaren begins with a discussion of the nature of urban sustainability and the urban sustainability goals for which indicators are needed. The author advises identifying a target audience, the purpose for which indicators will be used and the relative number of indicators needed. The next step is to choose an indicator framework (goal-based, issue-based, sectoral, domain-based, causal, and combination). MacLaren suggests defining indicator selection criteria and lists 12 of these. A set of potential indicators is selected and evaluated against the mentioned criteria. The final step is choosing a final set of indicators and testing their effectiveness. The author states that sustainability indicators differ from other indicators primarily in the way they are developed. They also have the ability to integrate two or more of the economic, environmental, and social aspects of sustainability into a single indicator. She concludes with a note about the time involved to create a widely accepted set of sustainability indicators. The text completes with case studies of the development and application of sustainability indicators in Seattle, Hamilton-Wentworth, and British Columbia. 
Maclaren, V., “Urban Sustainability Reporting,” APA Journal, vol 62, No. 2 (1996), pp 184-202.

This article provides a concise methodology for evaluating urban sustainability. The author draws on three North American examples to illustrate the process. She describes the types of sustainability indicators and walks through a nine-step process for evaluating urban sustainability. The indicator frameworks described are domain-based, goal-based, sectoral, issue based, causal, and combination. The framework selected depends on the target audience and the purpose for which indicators will be used. Indicators must be scientifically valid, representative, responsive, and accurate; in addition, data must be available. Final indicator evaluation should focus on relevance to sustainability goals, comparability, relationship to thresholds/targets and ease of understanding. The presentation and content of an urban sustainability report again depends on the target audience. Appendices should contain detailed information. The author concludes that it is too early to determine the effectiveness of urban sustainability reporting toward detecting progress or influencing policy. She questions whether it is possible to create a widely accepted set of sustainability indicators.

\section{Mclsaac, G., and M. Brun, Indices of Sustainable Systems and Sustainable Design: An Overview of Literature on the Concept of Sustainability and Efforts To Develop Indicators of Sustainability (1999).}

This report is an in-depth discussion of indicator development. It focuses on indicators originating from several different agencies, groups, and individuals. Two basic trends in indicator development can be discerned. The first responds to the demands of more complex models and gives rise to sets of increasingly numerous indicators. The second trend is the continuing search for "summary" indicators. These indicators will serve as useful signals, announcing serious environmental changes, but crude in that they do not provide much information on just what these changes are or what should be done in response. These two trends are not mutually exclusive. A process of adaptive management is recommended in developing suites of indicators that honor the concerns of the stakeholders and address conservation of resources, species, and ecosystem processes.

\section{Munasinghe, M., and W. Shearer, eds., Defining and Measuring Sustainability: The Biogeophysical Foundations (The International Bank for Reconstruction, Washington DC, 1995).}

The International Conference on the Definition and Measurement of Sustainability: The Biological and Physical Foundations took place in June 1992. Its goal was to explore prospects for defining sustainability and estab- 
lishing a set of sustainability measures, in a scientifically rigorous manner. This volume presents the highlights of the conference, and is divided into sections on key concepts and terminology, case studies, and managed ecosystems. The editor clearly distinguishes between sustainability and sustainable development. Sustainability involves interactions between biogeophysical, economic, social, cultural, and political systems. The theme of this conference was to define and measure biogeophysical foundations of sustainability.

\section{National Research Council, Ecological Indicators for the Nation (National Academy Press, Washington DC, 2000).}

This book reports findings of a scientific evaluation of indicators to monitor ecological changes from both natural and anthropogenic causes. The Indicators Committee (established by the National Research Council) decided that its main task was to identify and characterize general ecological indicators that could inform the public and decisionmakers about the overall state of the nation's ecosystems and how those ecosystems may be changing due to anthropogenic and other pressures. This book identifies criteria for evaluating biological indicators, evaluates methods of indicator development, provides examples of indicators that have proven useful, and identifies areas where further research might yield better indicators. It also attempts to examine environmental conditions and trends that should be monitored. It attempts to assess whether new approaches might better characterize some ecosystem aspects that have been difficult to characterize up to this point. The authors place indicators in three categories: ecosystem extent and status, ecological capital, and ecosystem functioning. Although the authors concentrated on national-level indicators, their methods could be used for developing local and regional indicators.

\section{Prescott-Allen, R., Barometer of Sustainability: Measuring and Communicating Wellbeing and Sustainable Development, vol 30 (Cambridge, International Union for Conservation of Nature and Natural Resources, 1997).}

This booklet describes how to organize and combine indicators from a wide range of issues to assess the state of people and the environment, and how to progress toward sustainable development. The most widely used common unit is money, but many issues and indicators of sustainability have no market price. An alternative to money is the performance scale. The Barometer of Sustainability is a performance scale with three unique characteristics: axes for human wellbeing and ecosystem wellbeing, a five-sector scale and ease of use by a wide range of users. The authors tell how to set 
and control the scale, organize indicators into a hierarchy (based on Agenda 21 chapters), calculate indicator scores, and communicate the results.

\section{SDI Group, Sustainable Development in the United States: An Experimental Set of Indicators (2001), available through URL:. \\ http://www.hq.nasa.gov/iwgsdi/Welcome.html}

This web site describes the mission, history, and progress of the Interagency Working Group on Sustainable Development Indicators (SDI Group). The SDI Group was formed in 1994 as a forum for the exchange of ideas, methods, and data related to sustainable development indicators and spearheads a national indicators effort in the United States. The Group collaborates with nongovernment organizations and the private sector to develop indicators to guide the government's progress. It has developed a proposed list of economic, environmental, and social indicators. The Group has participants from 12 Federal departments and agencies, and reports to the Council on Environmental Quality in the Executive Office.

\section{Sustainable Measures (2002), available through URL: http://www.sustainablemeasures.com/}

This web site provides an overview of sustainability and sustainable development. Definitions given include Webster's, IUCN, Sustainable Seattle, Friends of the Earth Scotland, Thomas Jefferson Sustainability Council, The Natural Step Four System Conditions, Santa Barbara South Coast, Our Common Future, Hamilton Wentworth Regional Council, World Business Council on Sustainable Development and Interfaith Center on Corporate Responsibility. The discussion on indicators includes how to select and organize indicators, what data sources are available, examples of good sustainability indicators and training materials. The Indicator Spotlight discusses some specific indicators in detail e.g., ecological footprint and total waste generated.

\section{Modeling}

Acevedo, W., and P. Masuoka, "Time-Series Animation Techniques for Visualizing Urban Growth," Computers \& Geosciences, vol 23 (May 1997), pp 423-35.

Time-series animation is a visually intuitive way to display urban growth. Animations of land-use change for the Baltimore-Washington region were generated in this study. Example time-series animations were created using a temporal Geographic Information Systems (GIS) database of the Baltimore-Washington area. Creating the animations involved generating raster 
images of the urban development, water bodies, and principal transportation routes; overlaying the raster images on a background image; and importing the frames to a movie file.

Batty, M., "Urban Evolution on the Desktop: Simulation With the Use of Extended Cellular Automata," Environment \& Planning, vol 30 (1998), pp 1943-1967.

The paper examines a spontaneous growth model that links macrostructure to microbehavior. The framework adopted to make this model operational is based on an extended cellular automata in which demand for location, seen as potential for development, drives actual development. Simulations are performed using StarLogo, Avid Cinema, and DataDesk software. The model can be used to predict if urban growth will result in the redevelopment of urban cores or the rise of edge cities. The model is limited in its ability to predict change, only able to do so in environments where there is a high degree of activity, innovation in the system, and within areas with a high growth rate.

\section{Cogan, C., "California Biodiversity Project: Application of Ecological Data to Biodiversity Analysis," Environmental Studies (University of California, Santa Cruz, 1997), available through URL: http://gis.ucsc.edu/Projects/cogan/cogan.htm}

The California Biodiversity Project is designed to examine the impacts of projected urbanization on natural habitats using models of biodiversity and spatially explicit urban growth. This combination of models is intended to predict which species and habitats will be most stressed over the short term (10 to 15 years) and the medium term (15 to 40 years). The project operates at the county scale, with portions of the analysis functioning over larger, physiographically defined planning regions. The emphasis of the research is on scale independence, and spatial portability of the biodiversity and urban growth models. With these goals in mind, Santa Cruz County in central California is serving as a pilot area. This area is adjacent to Monterey Bay and the Pacific Ocean, allowing a variety of ecological factors to be modeled including coastal influences, agriculture, steep terrain, rivers, forests, and open grasslands.

\section{Costanza, R., and T. Maxwell, "Spatial Ecosystem Modeling Using Parallel Processors," Ecological Modeling, vol 58 (1991), pp 159-183.}

The authors developed a system that links commercially available GIS for managing spatial data with a commercially available general dynamic simulation system for developing unit models (STELLA super ${ }^{\mathrm{TM}}$ ) and a Spatial Modeling Package (SMP) that we developed for linking the unit models into 
a spatial array, handling horizontal exchanges, and running the array as a spatial model. The spatial model code is executed on either transputers (parallel processors) resident in a desktop microcomputer or on a remote Connection Machine parallel mainframe computer with $64 \mathrm{~K}$ processors. Resulting time series maps are readable by the GIS system for further display and analysis.

\section{Couclelis, H., "From Cellular Automata to Urban Models: New Principles for Model Development and Implementation," Environment and Planning, B: Planning and Design, vol 24 (1997), pp 164-174.}

This article examines the integration of GISs with cellular automata (CA) based urban models. This integration has helped moved CA models from the realm of instructive metaphors to that of potentially useful qualitative forecasting tools. Such models can now be fully interactive for exploratory purposes, and they can be based on actual data. New problems, however, arise as the formal integrity of the original CA framework is lost through successive relaxations of the assumptions and as the resulting complicated models become increasingly difficult to implement and understand. This paper proposes that the theoretical problem can find a satisfactory answer in the notion of proximal space and the practical one can be handled successfully within a formalism of geo-algebra, a mathematical expression of proximal space that builds a bridge between GIS data and operations, and traditional urban and regional planning.

\section{Deal, B., C. Farello, et al., "A Dynamic Model of the Spatial Spread of an Infectious Disease: The Case of Fox Rabies in Illinois," Environment Modeling and Assessment, vol 5 (2000), pp 47-62.}

This paper describes development of a spatially explicit computer model that examines the dynamic spread of fox rabies across the state of Illinois, and evaluates possible disease control strategies. The ultimate concern is that the disease will spread from foxes to humans through the pet population. Modeling the population dynamics of rabies in foxes requires comprehensive ecological and biological knowledge of the fox and pathogenesis of the rabies virus. Variables considered including population densities, fox biology, home ranges, dispersal rates, contact rates, and incubation periods, can greatly effect the spread of disease. Accurate reporting of these variables is paramount for realistic construction of a spatial model. The spatial modeling technique utilized is a grid-based approach that combines the relevant geographic condition of the Illinois landscape (typically described in a georeferenced database system) with a nonlinear dynamic model of the phenomena of interest in each cell, interactively connected to the other appropriate cells 
(usually adjacent ones). The resulting spatial model graphically links data obtained from previous models, fox biology, rabies information and landscape parameters using various hierarchical scales. This makes it possible to follow the emergent patterns and facilitates experimental stimulus/result data collection techniques. Results of the model indicate that the disease would likely spread among the native healthy fox population from East to West, and would occur in epidemiological waves radiating from the point of introduction, becoming endemic across the State in about 15 years. Findings also include the realization that, while current hunting pressures can potentially wipe out the fox in the State, some level of hunting pressure can be effectively used to help control the disease.

Hannon, B., and M. Ruth, Dynamic Modeling (Springer-Verlag, New York, 1994).

This book explores the dynamic process in systems. Modeling Dynamic Economic Systems uses STELLA and MADONNA software to apply methods of computer modeling to a wide range of real world phenomena. The model demonstrates how to make informed decisions about economic performance and environmental quality.

Hannon, B., and M. Ruth, Modeling Dynamic Biological Systems (Springer-Verlag, New York, 1997).

This book is an introduction to dynamic systems modeling and how it can be used to provide insight to biological problems. The models included range from ecosystems to individual cells. The models exemplify the growing importance of improving our understanding of the characteristics and internal relationships that govern the system's behavior. The book clearly illustrates problems from a "dynamic systems" perspective and shows how to use technical programs as a tool to model biological systems. The text presents the means to build a greater understanding of the phenomena we see, the context of the problems that confront us, and the potential and expected effects of any interventions we may make.

Harris, R.I.D., and A. Liu, "Input-Output Modelling of the Urban and Regional Economy: The Importance of External Trade," Regional Studies, vol 32, No. 9 (1998).

This article presents information on a study that described the consequences of using different approaches to estimating regional trade vectors for use in an input-output table. Trade data and regional input-output modeling are used to demonstrate these concepts. The authors present a hybrid approach to input-output modeling. 
Hobish, M., "GIS Aids in Analysis of Urban Growth Effects," American City \& County, vol 114, No. 2 (1999), p 44.

This article provides information on the Project Atlanta Land-use Analysis: Temperature and Air-quality (ATLANTA) study. The authors use GIS and other technologies to study the effects of urban growth on the region's climate and air quality.

Jepson, W., and S. Friedman, "Simcity of Angels," Civil Engineering, vol 68, No. 6 (1998), pp 44-47.

Using advanced computing techniques, UCLA researchers are developing a virtual model of the entire $4000 \mathrm{sq}$ mi Los Angeles basin. Accurate to the level of graffiti on the walls and store window signs, the database for the model will soon reach 1 terabyte ( 1 trillion bytes) in size. The goal of the model is to help urban planners and others in solving urban design problems - for example, an architect could view the effect of a new development on an existing community and make appropriate changes before the design is completed. Other possible applications for the modeling technology include accurate tracking for emergency response teams, interactive hazardous waste simulations for students, mapping of conduits, wiring, and other in-wall elements for ease of maintenance, and in-car navigations systems.

\section{Johnston, R.A., and T. d.I. Barra, Comprehensive Regional Modeling for Long-Range Planning Linking Integrated Urban Models to Geographic Information Systems (1999), available through URL: http://www.modelistica.com/papers/sac/}

This study demonstrates the sequential linking of two types of models to permit the comprehensive evaluation of regional transportation and landuse policies. First, the authors operated an integrated urban model (TRANUS), which represents both land and travel markets with zones and networks. The travel and land-use projections from TRANUS are outlined, as this is the first application of a market-based integrated urban model in the United States. Second, the land-use projections for each of the 58 zones in the urban model were fed into a GIS-based land allocation model, which spatially allocates the several land uses within each zone according to simple accessibility rules. This is one of the first attempts to link these two types of models for regional policy assessments. Pairing these two types of models allows the user to gain the advantages of the urban models, which represent spatial competition across a region and produce measures of user welfare (traveler and locator surplus), and the advantages of the GIS land allocation models, which produce detailed land-use maps that can then be used for environmental impact assessment. 
Kilkenny, M., "Explicitly Spatial Rural-Urban Computable General Equilibrium," American Journal of Agricultural Economics, vol 81, No. 3 (1999), pp 647-652.

This article explains a computable general equilibrium (CGE) approach to modeling the implications of rural remoteness, low density, and dependence on natural resource industry. Information on urban agglomeration economies and congestion costs is essential to the model. Details on prices and market structure are outlined in the article. The author discusses labor migration and firm relocation.

Landis, J.D., "Imagining Land Use Futures: Applying the California Urban Futures Model," Journal of the American Planning Association, vol 61 (Autumn 1995), pp 438-57.

This article examines the California Urban Futures Model, a model designed to help planners, elected officials, citizens, and others create and compare alternative land-use policies. The model is inherently political and subdivides land by jurisdictional units for analysis purposes. The article explains the model's logic and how it works. The model is very data intensive and is used in conjunction with GIS as a mapping tool. It demonstrates an application of the model in predicting regional and subregional growth using Sacramento and the San Francisco Bay area as test cases.

Landis, J., and M. Zhang, "The Second Generation of the California Urban Futures Model, Part 1: Model Logic and Theory," Environment and Planning, vol 30 (1998), pp 657-66.

The second generation of the California Urban Futures Model (CUF II) tries to remedy the shortcomings of the first generation model. Unlike the first model, it includes multiple sectors, allows different land uses to bid against each other for preferred sites, is calibrated against real experience, and includes a "pseudo-pricing dynamic" into the development spillover process.

Lu, Kang Shou, and Jeffery Allen, Modeling and Predicting Future Urban Growth in the Charleston Area (1998), available through URL:

http://www.strom.clemson.edu/teams/dctech/urban.html

This growth projection study builds on another study completed by the Berkeley-Charleston-Dorchester Council of Governments (BCD COG), the University of South Carolina, and the South Carolina Department of Natural Resources. That study investigated urban growth in the greater Charleston metropolitan area from 1973 to 1994 and found that over the 21-year period, urban land-use growth has exceeded population growth by a 6:1 ratio. As South Carolina is targeted as one of the top 10 retirement states in the United States, and Charleston one of the top two regions in South Carolina, 
a fairly rapid growth scenario in the Charleston area is expected. Continued land transformation has certain negative impacts and eventually will fundamentally change the three-county area.

Makse, H.A., S. Havlin, et al., "Modelling Urban Growth Patterns," Nature, vol 377, No. 6550 (1995), pp 608-612.

Predicting urban growth is important for practical reasons, and also for the challenge it presents to theoretical frameworks for cluster dynamics. Recently, the model of diffusion limited aggregation (DLA) has been applied to describe urban growth, and results in tree-like dendritic structures which have a core or "central business district" (CBD). This article proposes and develops an alternative model to DLA that describes the morphology and the area distribution of systems of cities, as well as the scaling of the urban perimeter of individual cities. The resulting growth morphology can be understood in terms of the effects of interactions among the constituent units forming an urban region, and can be modeled using the correlated percolation model in the presence of a gradient.

Pijanowski, B.C., D.T. Long, et al., A Land Transformation Model: Conceptual Elements, Spatial Object Class Hierarchies, GIS Command Syntax and Application for Michigan's Saginaw Bay Watershed (Land Use Modeling Workshop, EROS Data Center, Sioux Falls, SD, 1997).

This presentation summarizes a project supported by a Cooperative Agreement between CIESIN (Consortium for International Earth Science Information Network, Saginaw, Michigan) and the USEPA. The objective of this project is to develop a land transformation model that integrates socioeconomics, land-use policy, and ecological processes using tools of GIS, landscape ecology, ecological modeling, hydrogeochemistry, and computer visualization. One major component of the land transformation modeling is an analysis of how past socioeconomic variables and policy decisions have influenced land-use change rates and patterns in the Saginaw Bay Watershed over the past 50 years. The major model components that have been identified by the researchers at Michigan State University on the project are: management authority (policies and institutional structures), socioeconomic driving variables, physical environment, land-use transition, land cover succession, human activity, pollution potential, hydrology, and ecological integrity. 
Ruth, M., and B. Hannon, Modeling Dynamic Economic Systems (Springer-Verlag, New York, 1997).

This book explores the dynamic process in economic systems, concentrating on the extraction and use of the natural resources required to meet economic needs. Modelling Dynamic Economic Systems uses STELLA and MADONNA software to apply methods of computer modeling to a wide range of real world phenomena. The models contained here demonstrate how to make informed decisions about economic performance and environmental quality.

\section{Schwirian, K.P., A.L. Nelson, et al., "Modeling Urbanism: Economic, Social and Environmental Stress in Cities," Social Indicators Research, vol 35, No. 2 (1995), pp 201-223.}

This article makes various observations about urbanism, and examined dimensions of urbanism that stress urban areas. The model offers measurement with standard composite variables used in social indicator research and examines causal connections within the urbanism factor.

\section{Spatial Modeling Environment (International Institute for Ecological Economics, Center for Environmental Science, University of Maryland System, 1999), available through URL: http://kabir.cbl.umces.edu/SME3/index.html}

The purpose of this research is to open the simulation arena to a much wider set of participants, and facilitate the application of computer modeling to the study of complex multiscale processes in support of science, education, and policy making on many levels. This site describes the integrated environment for high performance spatial modeling called the Spatial Modeling Environment (SME). This environment, which transparently links icon-based modeling environments with advanced computing resources, allows modelers to develop simulations in a user-friendly, graphical environment, requiring no knowledge of computer programming. Automatic code generators construct (spatial) simulations and enable distributed processing over a network of parallel and serial computers, allowing transparent access to state-of-theart computing facilities. The environment imposes the constraints of modularity and hierarchy in model design, and supports archiving of reusable model components defined in the Modular Modeling Language (MML). 
Trame, A.M., S.J. Harper, et al., The Fort Hood Avian Simulation Model: A Dynamic Model of Ecological Influences on Two Endangered Species (U.S. Army, Construction Engineering Research Laboratory [CERL], Champaign, IL, 1997).

This report describes development and use of the Fort Hood Avian Simulation Model (FHASM), a dynamic, spatially explicit model of ecosystem processes and population dynamics of Black-capped Vireo and Golden-cheeked Warbler at Fort Hood. Using FHASM to simulate different scenarios of management decisions and land-use policies, managers may discover improved strategies for control of brood parasitism by the Brown-headed Cowbird and for enhancement of suitable habitat for the Black-capped Vireo and Golden-cheeked Warbler. The model provides information exchange among six submodels: Management, Accidental Fire, Habitat, Avian, Map Input, and Simulation. Ultimately, FHASM may assist in developing a management plan that will ensure the viability of both endangered species over long periods of time.

Westervelt, J.D., B.M. Hannon, et al., A Dynamic Simulation Model of the Desert Tortoise (Gopherus agassizii) Habitat in the Central Mojave Desert (CERL, 1997).

This report describes the development of a dynamic, spatial, ecological model designed to help manage and protect the endangered desert tortoise living at Fort Irwin, an Army training center in the Mojave Desert. It is a generic prototype of the kind of tool needed to predict potential consequences and the degree of severity that highly disruptive land uses can have on the natural environment.

Westervelt, J.D., B.M. Hannon, et al., Dynamic, Spatial, Ecological Modeling: A Demonstrated Simulation of the Sage Grouse Habitat at the Yakima Training Center (CERL, 1995).

This study created a working dynamic spatial model of a selected eco-system using a cellular approach. A landscape was divided into regular cells. A single ecosystem model was developed with STELLA, and then applied simultaneously to each cell. The model was demonstrated using data on the Sage Grouse at the Yakima Training Center, WA. This exercise demonstrated the potential effectiveness of a suite of software capabilities designed to facilitate landscape design, development, and simulation.

White, R., and G. Engelen, "Cellular Automata as the Basis of Integrated Dynamic Regional Modeling," Environment and Planning B: Planning and Design, vol 24 (1997), pp 235-246.

This article presents an integrated model of regional spatial dynamics consisting of a cellular automata-based model of land use. The authors discuss 
the implications for the use of integrated dynamic spatial models, and demonstrate the integrative role of a cellular automata-based models. The article illustrates the operation of the model and shows how it can be used in a planning context.

White, R., and G. Engelen, "The Use of Constrained Cellular Automata for HighResolution Modeling of Urban Land-Use Dynamics," Environment and Planning B: Planning and Design, vol 24 (1997), p 323-343.

This article presents information on cellular automata and looks at the evolution of urban land use in Cincinnati, OH. Information on land use in a 113-cell neighborhood is presented to illustrate the model. The authors claim that cellular automata may be useful in the planning context. Statistical information pertaining to cellular automata is presented to further illustrate the study.

Wu, F., and C.J. Webster, "Simulation of Land Development Through the Integration of Cellular Automata and Multicriteria Evaluation," Environment and Planning B: Planning and Design, vol 25 (1998), pp 103-26.

This article proposes the use of cellular automata as a method of exploring the behavior of the self organizing system known as the city. The authors view the city as a biological system, but one with a complex set of transition rules that attempt to capture the richness of land conversion behavior in the simplifying methods of cellular automata simulation. The authors' contribution to cellular automata research is to integrate a multi-criteria analysis into the model to define nondeterministic, multidimensional, and multilevel transition rules. The model is loosely tested in the text on fast growing sections of Southern China.

\section{Wyly, E.K., and D.J. Hammel, "Modeling the Context and Contingency of Gentrification," Journal of Urban Affairs, vol 20, No. 3 (1998), pp 303-326.}

This article presents an empirical analysis of how gentrification altered the socioeconomic profile of the inner areas of four United States cities between 1960 and 1990. The article discusses the context of gentrification and the problems in modeling gentrification. A stepwise discriminant analysis is used, facilitating measurement of the long-term impacts of reinvestment and social change in the context of the entire central-city housing market. 


\section{Planning}

Aberley, D., Futures by Design: The Practice of Ecological Planning (New Society Publishers, British Columbia, Canada, 1994).

This book covers the history and theory of ecologically sound planning, and introduces a variety of planning perspectives including permaculture, social ecology, participatory planning, and bioregionalism.

Bolan, R., T. Luce, et al., Can Urban Growth be Contained? (Arizona State University, 1997), available through URL: http://www.asu.edu/caed/proceedings97/bolan.html

Challenging traditional urban theory, the authors warn that growth boundary strategies are based on outmoded notions of urbanization processes. This paper, using an analysis of the Twin Cities metropolitan region, presents an emerging theory of "postmodern" urban development based on social restructuring and a physical decentralization to the suburbs. Their research has profound implications for growth management.

\section{Brugmann, J., "Planning for Sustainability at the Local Government Level," Environmental Impact Assessment Review, vol 16, No. 4-6 (1996), pp 363-379.}

The author describes local responses to Article 28 of Agenda 21 from the United Nations Earth Summit in 1992. More than 1500 local governments in 49 countries established local Agenda 21 processes. A number of local definitions of sustainable development are offered. They share the decisionmaking criteria as follows: development decisions must balance demands of sustaining local economic, community, and ecological systems; both the local and global impact of development must be considered; and longterm sustainability must be balanced with equity issues. The author points out that traditional environmental planning cannot meet the aims of sustainable development. He details adaptations of environmental planning that are required and shows, through the use of local examples, how this can be accomplished. Five key areas discussed are: (1) maintaining the integrity of community development through the development of participatory approaches; (2) creating a common picture of current development conditions; (3) assessing systemic problems and requirements; (4) measuring the global impacts of local actions; and (5) maintaining strategic control of local development processes in the face of regional and global pressures. The author concludes that the most common measure taken by local governments is stakeholder participation. He states that moving toward sustainability will require further local feedback mechanisms. 
Campbell, S., "Green Cities, Growing Cities, Just Cities?: Urban Planning and the Contradictions of Sustainable Development," Journal of the American Planning Association, vol 62, No. 3 (1996), pp 296-312.

This article examines the difficulty in balancing environmental, economic, and social justice concerns in the planning process. The author constructs a triangle diagram to illustrate the dilemma. The points of the triangle represent social justice, environmental protection, and economic development. Sustainable development is achieved when a planner successfully balances these three concerns and lays in the middle of the triangle. The author claims that we are at a point in time where sustainability has won the battle of public ideas, but there is a need to bridge the gap between theory and practice. The author calls for planners to stand at the center of the triangle to implement sustainable development practices.

Chengri Ding, G.J.K., and Lewis D. Hopkins, Managing Urban Growth with Urban Growth Boundaries: A Theoretical Analysis (Department of Urban and Regional Planning, University of Illinois at Urbana-Champaign, 1996), available through URL: http://www.cfpa.org/issues/sprawl/ugb.html

This paper develops a theoretical model in which establishing an Urban Growth Boundary (UGB) and expanding it at distinct points in time can increase social welfare when a congestible public good is priced at average cost and urban infrastructure is fixed or lumpy. The model is cast in the framework of a monocentric, linear city with smoothly expanding bid rent functions that fall with distance from the urban center. As such, the model ignores many salient features of the urban landscape that planners must consider when designing actual UGBs.

Davidson, Clive, "Simulated Cities: The Game Grows Up," New Scientist, vol 146 (1995), pp 34-7.

This article discusses architects and developers use of computer simulations to enhance construction results. Examined are the simulation of the San Diego Convention Center at David Hughes' Reality Centre, and computer simulation use by the University of California at Los Angeles and local planners to inform residents about plans for rebuilding city sections devastated by the 1994 earthquake.

Kienitz, R., "Smart Growth: Coming to a Place Near You," Transportation Quarterly, vol 53, No. 4 (1999), pp 10-13.

This article focuses on the implementation of smart growth policies in the United States. The text outlines the effects of policies on suburb communi- 
ties, public views on smart growth, and the distinction between sprawl and suburbs. Issues on affordable housing and the capability of the U.S. political culture to create smart growth are also discussed.

\section{Klosterman, R., "Planning Support Systems: A New Perspective on Computer-Aided Planning," Journal of Planning Education and Research, vol 17 (1997), pp 45-54.}

This article examines the changing views of planning and computer-based information that provide the foundations for a new perspective on computerassisted planning. The idea is advanced that the use of computers has been an "imminent revolution" for 30 years. The use of computers has increased greatly, yet they have not changed the planning process fundamentally. It begins by tracing the evolving view of planning as applied science in the $1960 \mathrm{~s}$, as politics in the $1970 \mathrm{~s}$, and then as communication in the $1980 \mathrm{~s}$. It then reviews the evolving concern of the information sciences with data in the 1960s, information in the 1970s, and knowledge in the 1980s. It concludes by suggesting that the increasingly popular topic of planning support systems (PSS) can be seen as continuing these trends to include broader concern with intelligence and collective design.

Krieger, A., "Beyond the Rhetoric of Smart Growth," Architecture: The AIA Journal, vol 88, No. 6 (1999), pp 53-57.

This article explores the meaning of the expression "smart growth" in urban planning. The author outlines the views of conservatives and liberals on growth management, and explains what the New Urbanism movement advocates. The author examines smart growth initiatives in the platform of former United States presidential candidate Al Gore.

Page, M., "Four Ways to Looking at City Building in America," Journal of Urban History, vol 25, No. 6 (1999), pp 848-859.

This article reviews four books on American cities: Fighting Sprawl and City all: Resistance to Urban Growth in the Southwest, by Michael F. Logan; Building a New Boston: Politics and Urban Renewal, 1950 to 1970, by Thomas H. O'Connor; City-Building in America, by Anthony M. Orum; and Rebuilding Cleveland: The Cleveland Foundation and Its Evolving Urban Strategy, by Diana Tittle. 
Sklar, F.H., and R. Costanza, "The Development of Dynamic Spatial Models for Landscape Ecology: Quantitative Methods," in M.G. Turner and R. Gardner, Landscape Ecology (New York, Springer-Verlag, 1991), pp 239-288.

\section{Sustainable Development Information Service, Global Trends - Urban Growth, available through URL: http://www.wri.org/wri/trends/citygrow.html}

This is the website for the think tank known as the Sustainable Development Information Service. The group has many research areas related to the world and urban population explosion, including agriculture, biodiversity, and economics.

USGS (2000), Gigalopolis: The Twenty-First Century System of World Cities, available through URL: http://www.ncgia.ucsb.edu/projects/gig

Gigalopolis is the growing urban structure containing billions of people worldwide. Urban settlements and their connectivity will be the dominant driver of global change during the twenty-first century. Intensely impacting land, atmospheric, and hydrologic resources, urban dynamics has now surpassed the regional scale of megalopolis and must now be considered as a continental and global scale phenomenon. Project Gigalopolis extends and refines the Clarke urban growth model enabling predictions at regional, continental, and (eventually) global scales.

\section{Policy}

AtKisson, A., "Developing Indicators of Sustainable Community: Lessons from Sustainable Seattle," Environmental Impact Assessment Review, vol 16, No. 4-6 (1996), pp 337-350.

This article describes the 5-year process that the Sustainable Seattle Forum used to answer the question "What legacy are we leaving to future generations?" The author presents this story in a detailed chronological format. It begins with the definition of sustainability by consensus ("long-term cultural, economic, and environmental health and vitality") by a diverse, volunteer group that at its peak numbered 150. The group defined three types of indicators. A final list of 40 indicators was researched and refined, based on available data. The individual indicators were not aggregated in an effort to retain systemic complexity and avoid difficulty of weighting. Benchmarks were not set. Instead, it was agreed that the direction of sustainability would be shown, using the image of an instrument panel. The indicators became well known in planning circles and were considered a model effort, 
particularly for its focus on linkages between indicators and the systems they measure. This article summarizes factors that contributed to the group's ultimate success and several general conclusions. Among them is the importance of balancing environmental, economic, and social interestsand that selection of indicators should balance technical requirements against the ability of the public to understand.

President's Council on Sustainable Development, Towards a Sustainable America: Advancing Prosperity, Opportunity, and a Healthy Environment for the $21^{\text {st }}$ Century (Washington DC, President's Council on Sustainable Development, 1999).

The President's Council on Sustainable Development (PCSD) was established by President Clinton in June 1993 to advise him on sustainable development and develop "bold, new approaches to achieve our economic, environmental, and equity goals." Formally established by Executive Order 12852, the PCSD was administered as a federal advisory committee under the Federal Advisory Committee Act. The 10 goals of the PCSD were: health and the environment, economic prosperity, equity, conservation of nature, stewardship, sustainable communities, civic engagement, population, international responsibility, and education.

\section{Case Studies}

Clarke, K.C., S. Hoppen, et al., "A Self-Modifying Cellular Automata Model of Historical Urbanization in the San Francisco Bay Area," Environment and Planning B: Planning and Design, vol 24 (1997), pp 247-261.

This article presents a cellular automata model of growth that is calibrated by predicting the present urban extent from the past. Past dates and urban conditions are chosen and calibrated to optimize the performance of the model. The method of calibration requires numerous data layers and is computationally intensive. In more complex models, computations take weeks of CPU time to do an entire calibration for a study region, but the authors claim that the effectiveness of the results justify the time expenditure. This paper challenges the use of historic intervals in cellular automata systems, and makes multiple calibrations by varying the number, temporal interval, and temporal extent of the urban calibration data. Also, the effectiveness of long-term versus short-term data for short-term prediction is tested. The authors claim that lessons learned from these calibrations are of use not only for future applications of this model, but in the more general context of urban modeling model calibration. 


\section{Costanza, R., F.H. Sklar, et al., “Modeling Coastal Landscape Dynamics,” BioScience, vol 40 (February 1990), pp 91-107.}

Protecting and preserving coastal ecosystems requires the ability to predict the direct and indirect, temporal, and spatial effects of proposed human activities. To study this, a process-based spatial simulation model was developed for the Atchafalaya-Terrebonne marsh-estuarine complex in south Louisiana called the coastal ecological landscape spatial simulation (CELSS) model. The model consists of 2479 interconnected square cells, each representing 1 square kilometer. Each cell contains a dynamic ecosystem simulation model, and each cell is connected to its four nearest neighbors by the exchange of water and suspended materials. The buildup of land or the development of open water in a cell depends on the balance between net inputs of sediments and local organic peat deposition on the one hand and outputs due to erosion and subsidence on the other hand. This balance is critical for predicting how marsh succession and productivity is affected by natural and human activities. The results of the model indicate complex and often counterintuitive behavior that, like the real system, is difficult to summarize. A few general conclusions can be made, however. Coastal marshes can adapt to future projected higher rates of sea level rise and serve as a buffer against future global sea level rise if the rates are moderate and the marshes are healthy. Past activities in the area that modified the hydrologic and sediment flow patterns have had significant influence on the evolution of the region. And finally, management options in the area can be effective at mitigating the effects of proposed human alterations, but cumulative effects make analysis of individual options in isolation risky.

\section{Federal Energy Management Program, Greening of the White House (Washington DC, U.S. Department of Energy, 1999).}

President Clinton announced the Greening of the White House Initiative on Earth Day 1993. The purpose of the initiative was to improve the energy and environmental performance of the White House complex. This is one of several annual reports documenting progress to date and describing opportunities identified during the previous year. Measures completed prior to this report saved $\$ 300,000$ annually and avoided atmospheric emissions of at least 845 metric tons of carbon each year. The Greening Plan can decrease White House energy and water consumption by 50 percent or more. Longterm initiatives focused on goals rather than specific actions, ensuring that the greening measures were permanent. Greening measures include building envelope, lighting, HVAC, plug loads, waste, vehicles, and landscaping. The report includes a brief history of the complex followed by a list of greening activities both completed and recommended/planned. "The Bottom Line" 
identifies annual energy savings, annual cost savings, and carbon emissions avoided for each energy efficiency measure in place. Another purpose of the report is to inform Americans of opportunities to make homes, offices, or businesses more energy efficient, environmentally sound, and comfortable. This initiative was further documented on an interactive CD-ROM, a web site, and a videotape documentary. FEMP also produced a Greening of Federal Facilities Resource Guide for Federal energy managers.

\section{Gunderson, L.H., C.S. Holling, et al., Barriers and Bridges to the Renewal of Ecosystems and Institutions (Columbia University Press, New York, 1995).}

This book is the result of a 3-year project involving a combination of prominent ecologists and social scientists, and reviews a series of regional examples in a broad-ranging exploration of the questions of whether institutions learn, and how ecosystems respond to management actions. To answer these questions, the team of researchers looked at common patterns of pathology in managed ecosystems, whereby resource exploitation leads to ecological, social, and institutional breakdown, followed by crisis and, in some examples, reform and learning. The text successfully explains the many ways in which resource management can be confounded by the temporal and spatial scales of ecosystem change. In doing so, it justifies its main conclusion that institutions should try to manage by change rather than simply react to it.

Hamilton, G., “Urban Jungle,” New Scientist, vol 161, No., 2178 (1999), pp 38-42.

This article focuses on the planned research of Steward Pickett, an ecologist and director for the Baltimore, MD Ecosystem Study. Pickett set out to study Baltimore as an ecosystem, examining its hydrology, microclimate, nutrient cycles, energy flow, and predator-prey relationships. The article includes details of past studies, what Pickett and his colleagues will examine in their study, the desired outcome, and the understanding of many strands of relationships that form the urban ecosystem and environmentally aware city planning.

Mazza, P., Best Urban Growth Planning in the Nation?: An Introduction to Region 2040, Portland's 50-Year Growth Management Plan (1995), available through URL: www.tnews.com/text/portland1.html

This article outlines and examines Portland's Region 2040 plan. The Region 2040 is a 50-year growth plan for the city that seeks to accommodate the projected 1 million additional people the city is projected to grow by in that time by expanding upward rather than outward. 
Oregon's Department of Land Conservation and Development, What is an Urban Growth Boundary? Facts About an Important Land-Use Planning Tool in Oregon's Statewide Planning Program, available through URL: http://darkwing.uoregon.edu/ pppm/landuse/UGB.html

This website gives the reader a basic understanding of what an Urban Growth Boundary (UGB) is and how it functions in the state of Oregon.

Puget Sound Regional Synthesis Model (PRISM), Urban Growth \& Population Impacts, available though URL:

http://www.prism.washington.edu/science/

This model synthesizes five other models to simulate the movement of water in the Puget Sound Region, from mountaintop to the bottom of the ocean. When the five models are coupled, the PRISM model will estimate climate and meteorological variables for the entire Puget Sound watershed at a 1-km horizontal resolution for 32 vertical layers in a three dimensional atmospheric column with an internal time step of 30 seconds and an external time step of 6 hours. This simulation drives a land surface process model which simulates the interception and infiltration of precipitation and solar radiation in the production of snow, snow melt, soil moisture, surface and ground water runoff, vegetation growth, and organic matter and nutrient production. These processes are modeled at a horizontal resolution of 30 to 150 meters on a daily time scale. The website contains wonderful illustrations and descriptions of the work being done.

Thomas Jefferson Sustainability Council Indicators of Sustainability: Interim Report (Charlottesville, Thomas Jefferson Planning District Commission).

This interim report was prepared by the Thomas Jefferson Sustainability Council which was given the charge to "Describe a future where our economic, human, social, and environmental health are assured." The group stated general concepts of sustainability and then translated them into 69 objectives. From this 159 indicators were developed. This is the region's first comprehensive set of indicators. It formed the basis for the Sustainability Accords of 1997 and the accompanying State of the Region report. 
Timlin, D., and D. Johnston, Exploring Spatial Relationships Between Property Value and Crime: A GIS and Statistical Study for Champaign, Illinois (University of Illinois, Department of Landscape Architecture, Urbana, IL, 1996).

\section{World Wide Fund for Nature, UNEP World Conservation Monitoring Center, et al.,} Living Planet Report 2000 (World Wide Fund for Nature, London, 2000).

The Living Planet Report 2000 uses the Living Planet Index (LPI) and the Ecological Footprint to quantify changes in the state of the Earth's natural ecosystems over time and to measure the human pressures on the natural environment from the consumption of renewable resources and pollution. It attempts to analyze geographic patterns in those pressures. The report calculates the index by region and the Ecological Footprint for individual countries. The LPI is a measure of the natural wealth of the Earth's forests, freshwater ecosystems, and oceans and coasts. It is the average of three ecosystem indices that measure the change over time of species. The LPI fell by 33 percent between 1970 and 1999 .

\section{Worldwatch Institute, Vital Signs 2001 (W.W. Norton \& Co, New York, 2001).}

The global trends documented in Vital Signs 2001-from the rapid increase in the use of wind power to the continued warming of the planet-will play a large role in determining the quality of our lives and our children's lives in this new century. This tenth volume in this series from the Worldwatch Institute shows in graphic form the key trends that often escape the attention of the news media and world leaders, trends that are often ignored by economic experts as they plan for the future. This book gives readers easy access to indicators that show social, economic, and environmental progress, or the lack of it. The carefully selected data have been distilled into "vital signs" from thousands of documents from government, industry, scientific bodies, and international organizations. This publication includes a CD containing data and graphics from the book.

\section{Worldwatch Institute, State of the World 2001 (W.W. Norton \& Co, New York, 2001).}

State of the World is the flagship publication of the Worldwatch Institute. The Worldwatch Institute's award-winning research team takes a fresh look at the most difficult challenge the world faces: how to build an environmentally sustainable economy before we do permanent damage to the natural systems that support our global civilization. From the thinning of the Arctic sea ice to the invasion of the mosquito-borne West Nile virus, State of the World 2001 shows how the economic boom of the last decade has damaged natural systems. The increasingly visible evidence of environmental dete- 
rioration is only the tip of a much more dangerous problem: the growing inequities in wealth and income between and within countries, inequities that will generate enormous social unrest and pressure for change. The authors argue that to solve the earth's environmental problems, we must simultaneously address the problems of the world's poor peoples. This publication includes a CD containing data and graphics from the book. State of the World 2001 is written in clear and concise language by the staff of the Worldwatch Institute, whose researches have been producing accurate, reliable studies of global environmental and social problems for more than two decades. The Institute's distinguished research team brings an interdisciplinary perspective to data from around the world, providing information on how to build a sustainable society.

\section{Yale Center for Environmental Law and Policy, 2001 Environmental Sustainability Index (World Economic Forum, Davos, 2001).}

The Environmental Sustainability Index is a measure of progress toward environmental sustainability developed for 122 countries. Scores are based on 22 core indicators. Each indicator combines a number of variables, for a total of 67 . The ESI allows quantitative comparison of environmental progress between countries. 


\section{Conclusion}

This work has provided the results of a preliminary investigation to identify and apply indices of sustainability for the Army installation. This report gives:

1. A detailed discussion of primary definitions needed to initiate the investigation (Chapter 2)

2. An outline of the steps required to derive a "dynamic systems modeling framework" (Chapter 3)

3. An annotated bibliography of past and current research in the area of sustainability indices (Chapter 4).

The principle of sustainability has gained international attention. However, efforts to attain sustainability have not advanced significantly despite consistent global evidence of the need. This stems from the difficulty in agreeing on a definition and developing a vision that supports sustainability goals. In order to move towards sustainability, these goals must be incorporated into a living plan with immediate and practical objectives including ways to measure progress. Planners are uniquely positioned to assist if not head the visioning process leading to development of sustainability indicators. Planners must incorporate sustainability goals and objectives into planning documents in the form of measurable indicators. Although a core set of global or national indicators would be helpful, it is vital that stakeholders develop a unique set of indicators for each local sustainability effort.

The continued degradation of the environment, the dwindling of vital resource stocks, and economic inequities will draw increasing attention to the need to improve sustainment of society, the economy, and the environment for future generations. Indicators are used to provide a record of conditions in order to evaluate trends, select management options that address problems, and measure the effectiveness of interventions toward improving them. Though the literature does not reveal a "best practice" for developing and using sustainability indicators, and there are few successful examples as guidance, it is imperative that informed and qualified individuals take steps to increase sustainability.

An integrated, comprehensive plan is essential to work toward sustainability. A plan is necessary to guide industry, government, and the public sector toward a common goal of sustainability with efficiency of effort and within a framework that 
supports public understanding and involvement. Central to the plan is a broadly accepted clear vision. Visioning often begins with agreeing on a definition for sustainability. This is an element common to many successful indicator efforts, including Sustainable Seattle (Maclaren 1996, cf. p 32). The vision points to a goal(s) and a number of objectives. Oregon has 10 sustainable community objectives. The plan is a road map to achieving sustainability and, like any comprehensive plan, it must be fluid, reviewed and updated periodically as conditions and priorities change.

Indicators are central to the sustainability planning process in order to measure progress with respect to goals. Groups embarking on indicator efforts have much information to draw on. The literature is replete with suggested indicator selection processes, criteria, frameworks, and lengthy lists of indicators.

Sustainability indicators are unique to each organization, but should contain a set of core indicators that are either basic in nature or cross borders. Core indicators are necessary where the "thing" to be measured is global, such as greenhouse gas emissions, where basic needs are described such as human health, or where comparisons are required such as with carbon tax schemes.

Indicators must be developed and adopted by an interdisciplinary team comprised of a cross-section of community members. Stakeholder participation includes community values as a factor in decisionmaking and reduces adversarial relationships between residents and government agencies. A unified vision is necessary in order to implement change.

In their current role, planners are the glue that binds a diverse set of interests and needs in their current role. City and regional planners are experienced in preparing comprehensive plans and other planning documents, and could readily adapt these skills and experience to facilitate creation of a community plan for sustainability. The increasing use of participatory planning techniques would greatly enhance sustainability planning efforts. Use of the regional approach in planning is also helpful when considering the variety of spatial and temporal scales necessary in planning for sustainability.

Planners are in a position to influence the use of resources through guiding the urban form. Incorporating principles of sustainability into planning implementation guidelines such as building codes, zoning ordinances, subdivision regulations, and municipal capital development plans is a planner's responsibility. Urban design and management initiatives such as open space preservation, urban growth boundaries, revitalization of existing towns, 'brownfield' redevelopment, and integrated planning of land-use and transportation are a few ways that planners are 
already moving in the direction of sustainability. As a minimum, indicators should be incorporated into these efforts.

Urban sustainability indicators are likely to become an important new planning tool, and, therefore, the curriculum for planners should include sustainability training. 


\section{CERL Distribution}

Chief of Engineers

ATTN: CECW-ET (2)

ATTN: CEHEC-IM-LH (2)

Engineer Research and Development Center (Libraries)

ATTN: ERDC, Vicksburg, MS

ATTN: Cold Regions Research, Hanover, NH

ATTN: Topographic Engineering Center, Alexandria, VA

Defense Tech Info Center 22304

ATTN: DTIC-O

7

$5 / 02$ 


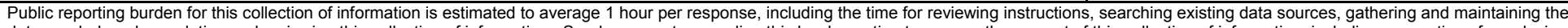

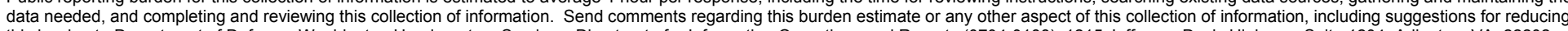

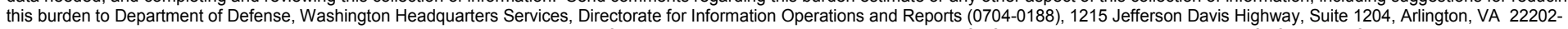

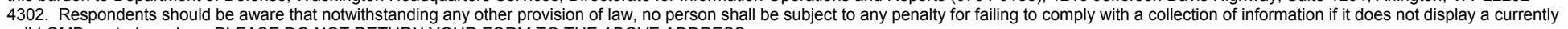
valid OMB control number. PLEASE DO NOT RETURN YOUR FORM TO THE ABOVE ADDRESS.
1. REPORT DATE (DD-MM-YYYY)
2. REPORT TYPE
3. DATES COVERED (From - To)

09-2002

Final

\section{TITLE AND SUBTITLE}

Sustainability Indices for Military Installations:

An Annotated Bibliography

5a. CONTRACT NUMBER

5b. GRANT NUMBER

5c. PROGRAM ELEMENT NUMBER

6. AUTHOR(S)

Elisabeth M. Jenicek, Brian M. Deal, and Adam Sagert

5d. PROJECT NUMBER

622784AT41

5e. TASK NUMBER

$\mathrm{X} 201$

5f. WORK UNIT NUMBER

\section{PERFORMING ORGANIZATION NAME(S) AND ADDRESS(ES)}

U.S. Army Engineer Research and Development Center (ERDC)

Construction Engineering Research Laboratory (CERL)

PO Box 9005

Champaign, IL 61826-9005

\section{SPONSORING / MONITORING AGENCY NAME(S) AND ADDRESS(ES)}

Headquarters, U.S. Army Corps of Engineers (HQUSACE)

441 G. St., NW.

Washington, DC 20314-1000 11. SPONSOR/MO
NUMBER(S)
8. PERFORMING ORGANIZATION REPORT NUMBER

ERDC/CERL TR-02-25

10. SPONSOR/MONITOR'S ACRONYM(S)

CEERD-CVT

1. SPONSOR/MONITOR'S REPORT

\section{DISTRIBUTION / AVAILABILITY STATEMENT}

Approved for public release; distribution is unlimited.

\section{SUPPLEMENTARY NOTES}

Copies are available from the National Technical Information Service, 5285 Port Royal Road, Springfield, VA 22161.

\section{ABSTRACT}

Army installations must "sustain" their own existence in the context of surrounding civilian communities, the environment, and the Army as a whole. Yet, "sustainability" is not a clearly defined concept. Army installations have no objective indicators of sustainability, and no clear path to achieve sustainability. The objectives of this study were to: (1) define what is meant by a "sustainable Army installation"; (2) identify and apply indices of sustainability for the Army installation; and (3) identify indicators of sustainability and ways to achieve sustainability that will enhance installation survivability and competitiveness as a platform for accomplishing the Army mission. This report contains a bibliography of past and current research in the area of sustainability indices.

\section{SUBJECT TERMS}

bibliography military installations

\section{SECURITY CLASSIFICATION OF:}

a. REPORT

Unclassified

\section{b. ABSTRACT Unclassified}

environmental management indices sustainable facilities

\begin{tabular}{c|c|c}
$\begin{array}{c}\text { 17. LIMITATION } \\
\text { OF ABSTRACT }\end{array}$ & $\begin{array}{c}\text { 18. NUMBER } \\
\text { OF PAGES }\end{array}$ & \\
& 60 & \\
\hline
\end{tabular}

19a. NAME OF RESPONSIBLE PERSON

Elisabeth M. Jenicek

19b. TELEPHONE NUMBER (include area code)

(217) 373-7238 